\title{
Controlling cyanotoxin occurrence
}

\author{
Drinking-water treatment
}

Gayle Newcombe, Lionel Ho, and José Capelo Neto

\section{CONTENTS}

Introduction

10.1 Treatment options for cyanobacteria and cell-bound cyanotoxins

10.1.1 Pre-oxidation

10.1.2 Physical separation processes

10.1.2.1 Conventional processes

10.1.2.2 Membrane filtration

10.1.2.3 Assessing the risk of toxin release and breakthrough of cyanobacteria and cell-bound toxins

$\begin{array}{ll}\text { 10.2 Treatment options for dissolved cyanotoxins } & 602\end{array}$

10.2.1 Physical processes

10.2.1.1 Adsorption

602

10.2.1.2 Membrane filtration

608

10.2.2 Chemical processes

609

10.2.2.1 Chlorine

609

10.2.2.2 Ozone

611

10.2.2.3 Other oxidants

10.2.2.4 By-product formation

10.2.3 Biological filtration

10.2.3.1 Assessing efficacy of treatment steps in eliminating dissolved cyanotoxins

10.3 Summary of treatment measures for the removal of cyanobacteria and associated cyanotoxins

10.4 After the water treatment plant - risks associated with treated water storage 
10.5 Assessing and reducing the risk of cyanotoxin breakthrough in drinking-water treatment in the context of a Water Safety Plan

10.6 Achievement of cyanotoxin guideline values References

\section{INTRODUCTION}

Drinking-water treatment is the last line of defence to ensure the provision of safe, clean water to consumers. The multibarrier approach where control points within the overall treatment process are identified and optimised, and their efficiency is monitored and verified - is now globally accepted as best practice for this purpose. Water suppliers using raw water with cyanobacteria at levels causing a cyanotoxin risk need to identify the points in the plant where either removal or release of toxins can occur, optimise the controls and minimise the risks of toxin breakthrough. This chapter describes the current state of knowledge about the treatment measures that are available for the removal of cyanobacteria and the toxins they produce, the monitoring regimes that can be undertaken to ensure the optimum performance of those measures, as well as validation programmes that can be run to ensure optimum choice and design of measures.

\section{I TREATMENT OPTIONS FOR CYANOBACTERIA AND CELL-BOUND CYANOTOXINS}

In many situations, most of the cyanotoxins will be cell-bound, while for cylindrospermopsin, a high fraction can occur in the dissolved state (see Chapter 2 and Box 5.1). Thus, any physical particle separation process that removes cyanobacterial cells without damage will offer an effective barrier to cyanotoxins, particularly microcystins. Section 10.1 describes the processes that can be applied to remove cells, while maintaining cell integrity. However, often pre-oxidation is applied for other treatment goals such as manganese removal or the improvement of coagulation, so it is also important for water suppliers to be aware of the potential risks of cell rupture and cyanotoxin release associated with the application of pre-oxidation.

\section{I.I Pre-oxidation}

Chemical oxidation can have a range of effects on cyanobacteria cells, from minor cell wall damage to cell death and lysis (Pietsch et al., 2002). 
Although improvement of the coagulation of algal cells through oxidation at the inlet of the treatment plant through a number of mechanisms has been reported (Petrusevski et al., 1996), this involves a high risk of damaging the cells and releasing metabolites into the dissolved state. For example, potassium permanganate, commonly used as a pre-oxidant to control manganese, can potentially damage cyanobacteria and release toxins without oxidising the released cyanotoxins (Dugan et al., 2018). Other common pre-oxidants include chlorine and ozone.

If pre-oxidation must be applied in the presence of cyanobacteria cells, the levels of oxidant should be sufficient to result in the residual required for the destruction of dissolved toxins (see section 10.2). If it is insufficient, this causes a risk of high levels of dissolved toxin and organic carbon adversely influencing subsequent removal processes and finished water quality.

Table 10.1 presents a summary of some of the literature on the oxidation of cyanobacteria and toxin release and destruction. Kinetic studies indicate clearly that the rate of cell membrane damage and toxin release is greater than the rate of toxin degradation. These results suggest that the oxidant doses required will vary depending on water quality parameters such as $\mathrm{pH}$, dissolved organic carbon (DOC) concentration and characteristics, the abundance of cyanobacteria, the size of the cyanobacterial filaments or colonies and the amount of intracellular and extracellular organic materials (IOM and EOM) associated with the cyanobacteria. Natural cyanobacterial samples contain more EOM, and cells are more likely to occur in larger colonies or filaments than in the cultured samples used in many studies. Therefore, if pre-oxidation must be practiced in the presence of potentially toxic cyanobacteria, a regular laboratory testing is important to ensure that the oxidant demand is met and the released toxins are destroyed. If this is not possible, it is best to cease pre-oxidation for periods during which cyanobacteria are abundant in the raw water.

\section{I.2 Physical separation processes}

Ideally, the number of cyanobacterial cells in the raw water is minimised by appropriate measures in the waterbody (Chapter 8) and its catchment (Chapter 7). Pretreatment using bank filtration is also very effective (Chapter 9). However, even where these measures reduce the concentration of cyanobacteria entering the treatment plant, where they still occur, multiple barriers are important, and this requires optimising removal of cells and toxins through treatment.

Two main processes can be utilised for the physical removal of cyanobacteria from raw water: conventional processes (e.g., coagulation/clarification and sand filtration) and membrane filtration (e.g., microfiltration $[\mathrm{MF}]$ and ultrafiltration $[\mathrm{UF}])$. 


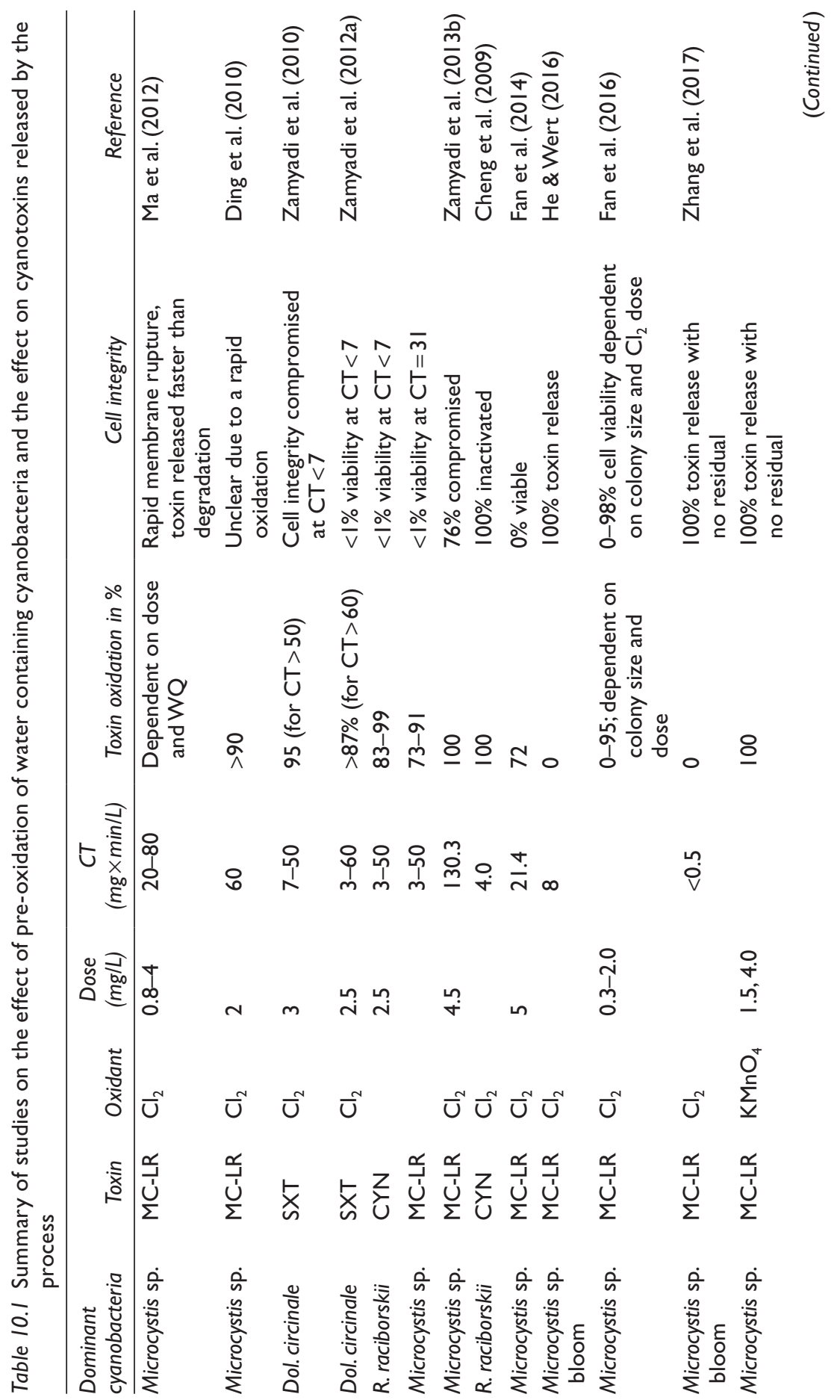




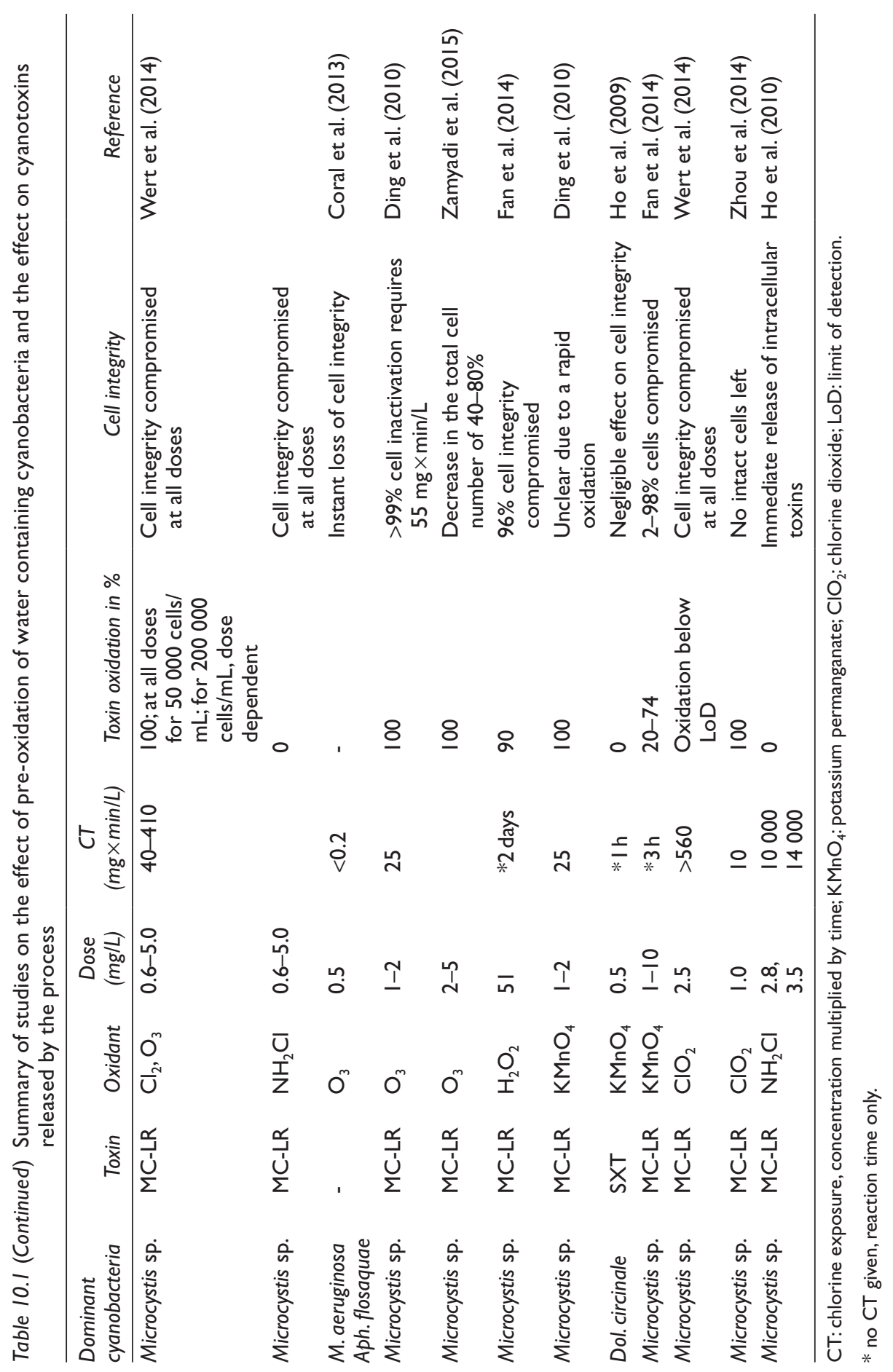




\section{I.2.I Conventional processes}

\section{Background}

Conventional treatment generally comprises coagulation and flocculation, followed by clarification and rapid media filtration. Coagulation and flocculation are processes that aggregate suspended particles through the addition of a chemical coagulant. Common coagulants used in water treatment include various aluminium and ferric salts, synthetic organic polymers or a combination of inorganic and organic coagulants. In the clarification step, the coagulated particles, or flocs, are separated from the water by processes such as sedimentation, dissolved air flotation (DAF) or upflow clarification processes. Two common alternatives to the full conventional process are direct filtration, where there is no clarification step, and contact filtration, where the flocculation and clarification steps are eliminated. While the coagulation process is ineffective for the removal of extracellular (dissolved) cyanotoxins, it is very effective in removing cell-bound cyanotoxins through the removal of the whole cyanobacterial cell (Drikas et al., 2001; Henderson et al., 2008; Newcombe et al., 2015).

\section{Effect of the cyanobacteria's specific morphology and characteristics of the specific coagulant}

The morphological characteristics of cells, in particular their size, shape and surface characteristics, may influence the efficiency of the coagulants used for the removal of cyanobacteria. One study showed that larger cells were more effectively removed, and within a size group, spherical cells were removed more effectively than elongated cells (Ma et al., 2007). Consequently, microscopy of cyanobacteria - even without identification to the species level - may be useful for optimising or predicting the effectiveness of the coagulation and flocculation process. Henderson et al. (2008) suggested that another indicator of the coagulant dose could be the surface area of the cells: smaller cells would require a higher dose than larger cells at an equivalent biovolume.

Some coagulants may be more effective than others for the removal of cyanobacteria, and the addition of polymers may, or may not, aid in the removal (Teixeira \& Rosa, 2006a; Teixeira \& Rosa, 2007; De Julio et al., 2010; Newcombe et al., 2015). In addition, it has been reported that proteins and other extracellular organic material (EOM) produced by some cyanobacteria may either inhibit (WHO, 2015) or enhance (Yap et al., 2012) the coagulation process. Cell removal efficiencies vary between species and even between strains of the same species, and depend on parameters such as the physiological stage of the cells, conditions of culturing (if grown in the laboratory), and characteristics of intracellular organic material (IOM) and EOM. 
The inconsistent findings in the literature indicate that coagulation efficiencies strongly depend on cyanobacteria species and water quality conditions, and choices should be made on a case-by-case basis according to the raw water quality, available processes and the achievement of other water quality goals (e.g., dissolved organic carbon [DOC] removal).

\section{Operational guidance for the coagulation step}

Through a comprehensive study of the application of conventional treatment for the removal of cyanobacteria, Newcombe et al. (2015) developed some practical guidelines using conventional jar testing, which is usually implemented on a routine basis for the optimisation of treatment processes. This research involved several cyanobacterial taxa (Microcystis spp., Raphidiopsis (Cylindrospermopsis) raciborskii, Dolichospermum circinale, Pseudanabaena sp. and Oscillatoria sp.) at a range of cell numbers, a range of waters and three coagulants (aluminium sulphate - alum; ferric chloride and aluminium chlorohydrate $-\mathrm{ACH})$. The authors demonstrated that cell removal of Raphidiopsis raciborskii (filamentous) was lower $(<90 \%)$ than that of the other species; however, for all cyanobacteria, the authors found that optimisation of the coagulation process for the common water quality parameters (DOC, or total organic carbon - TOC and/or turbidity) resulted in the optimum removal of cyanobacteria. This finding is in agreement with further studies which demonstrated that the conditions for optimum turbidity removal corresponded with optimum cyanobacteria removal (De Julio et al., 2010; Şengül et al., 2016), although Newcombe et al. (2015) found that turbidity was a good indicator of the removal of cyanobacteria only in raw water with a turbidity of 10 NTU (nephelometric turbidity units) or above. While such literature is a useful starting point for planning the optimisation of coagulation, the most effective way forward for optimising coagulation will be to test efficacy under the respective local conditions during phases in which treatment is particularly challenged by blooms.

It should be noted that while the process of coagulation itself does not cause damage to cells, some cell damage and toxin release can occur if the $\mathrm{pH}$ of solution decreases to below 6 (Qian et al., 2014). Thus, in the presence of cyanobacteria, the $\mathrm{pH}$ of the coagulation step should be maintained above 6, even when a lower $\mathrm{pH}$ may be optimal for the removal of DOC or colour (e.g., when ferric salts are used as the coagulant).

\section{Treatment steps following coagulation}

After coagulation, the flocs must be removed by downstream processes. Mouchet and Bonnelye (1998) provided a summary of the types of clarifiers used by water suppliers. They determined that sludge blanket clarifiers (which keep the overflow rate such that it is less than the settling rate of the 
sludge, allowing the "blanket" of sludge to form) were more effective for cyanobacterial cell removal than static settlers, where the sludge is allowed to settle to the bottom of the clarifier and the clarified water is removed from the top through weirs. It is important to realise that this only applies if the sludge blanket clarifier is operated under optimal conditions to minimise clarified water turbidity. Dissolved air flotation (DAF), where small air bubbles are released from the bottom of the flotation tank and the coagulated/flocculated particles, or flocs, are captured by the bubbles and float to the surface, is particularly effective for the removal of cyanobacteria as many species contain gas vacuoles that provide buoyancy, leading to more efficient clarification by flotation than by sedimentation (Teixeira \& Rosa, 2006a; Teixeira \& Rosa, 2007; Aparecida Pera do Amaral et al., 2013). However, not all water sources impacted by cyanobacteria are suitable for DAF as, in general, only waters of high colour and low turbidity are amenable to flotation processes.

It is important to be aware that while optimisation of coagulation and clarification will maximise the removal of cyanobacteria under given conditions, $100 \%$ removal has seldom been reported in the literature. Even in the best-case scenario, where optimised removals may be in the range of 95-99\% of cells, the presence of high cell numbers in the source water could result in significant cell concentrations remaining after clarification. For example, if only 50000 cells $/ \mathrm{mL}$ of toxic Microcystis aeruginosa entered an optimised treatment plant which achieves $98 \%$ removal through alum coagulation and sedimentation, the concentration of cells at the end of the clarification step could still be of the order of 1000 cells $/ \mathrm{mL}$, which (at a cell radius of $5 \mu \mathrm{m}$ ) would correspond to a biovolume of $0.5 \mathrm{~mm}^{3} / \mathrm{L}$. Although the barrier was optimised, this concentration of uncoagulated cells is above Alert Level 1 as described in section 5.1.2 for raw water risk. Due to the freefloating nature of cyanobacteria, this can lead to an accumulation within the treatment train, for example, in the clarifier, and a rapid increase in the cell number and toxin concentration, as has been described by Zamyadi et al. (2012b) and Zamyadi et al. (2013a).

Many plants carry out intermediate chlorination, prior to the filters, for manganese removal, or to reduce particle counts in filtered water. In the event of cell breakthrough, as described above, this practice should be either terminated or optimised to ensure the oxidation of cells and released toxins.

Filtration is usually employed immediately after the coagulation and clarification process. A variety of granular media are used in these filters, including sand, anthracite, coal and activated carbon. Although filtration is effective in the removal of cyanobacteria associated with flocs, individual cells and/or filaments are not always removed, resulting in breakthrough of cells into the filtered water. Different genera of cyanobacteria may also respond differently to granular filtration: Zamyadi et al. (2013b) reported poor coagulation and a significant breakthrough of 
Aphanizomenon cells after filtration, while the removal was effective for Microcystis, Anabaena and Pseudanabaena in the same plant. Dugan and Williams (2006) evaluated the efficiency of downflow in-line filtration (coagulation followed by direct filtration) in the removal of cyanobacteria cells after abrupt increases in hydraulic loading rates. They observed a consistent impact of cell morphology on cyanobacteria cell breakthrough in all experimental trials, where effluent concentrations of $M$. aeruginosa (spherical shape) were consistently higher than for Aphanizomenon flosaquae (filamentous).

\section{Sludge management after coagulation}

While coagulation and clarification effectively separate the cyanobacteria from the treated water, up to $98 \%$ of the cell-bound cyanotoxins are consequently concentrated in the sludge, or float in the case of DAF; therefore, appropriate handling and disposal of the treatment plant residuals can become a challenge. Over a period of time, cell damage and lysis can occur in sludge produced by coagulation, releasing cyanotoxins (Drikas et al., 2001; Ho et al., 2012a; Zamyadi et al., 2018). This is an issue at long sludge detention times in treatment plant clarifiers where milligram concentrations of microcystins have been reported (Zamyadi et al., 2012b). When cell damage and toxin release from the accumulated sludge occurs during the clarification step, this may pose a significant risk if the treatment plant has no further barriers for dissolved toxin removal. To control this risk, it is therefore important to remove sludge frequently from within the treatment train during a toxic cyanobacterial challenge.

Also, more frequent backwashing of filters may be required, particularly in direct filtration plants, to prevent floc build-up and subsequent cyanotoxin release (Ho et al., 2012a), as cyanobacteria contained in flocs within the filter medium may lyse and release cell-bound toxins into the filter effluent. In particular, backwashing of filters prior to temporary filter shutdown could reduce the possibility of cyanotoxin release. The authors also demonstrated that cyanobacteria appear to be protected within the flocs and were not significantly damaged by rigorous backwashing procedures.

Once the sludge and backwash water are removed from the plant, care needs to be taken to manage the toxic waste appropriately. This issue has been the focus of a number of publications in the international literature due to the growing concern about conserving resources and reusing both treatment plant solids and supernatant water from the sludge treatment facilities (Ho et al., 2012b; Sun et al., 2013; Li et al., 2015; Dreyfus et al., 2016; Pestana et al., 2016).

The management of cyanobacteria-laden sludge is a complex challenge potentially multiple biological, chemical and physical processes taking place simultaneously in the sludge treatment facility. Some of the 
processes that may occur in sludge lagoons or sludge thickeners include (Pestana et al., 2016):

- reduced cell viability, with consequent lysis and metabolite release;

- cell multiplication in the sludge or supernatant;

- possible increase in metabolite production due to stress;

- biological degradation of metabolites;

- physical and chemical processes resulting in a decrease in metabolite concentrations.

All of these processes will be dependent on

- type of cyanobacteria and toxin;

- rate of biological and chemical degradation;

- rate of physical loss through adsorption;

- rate of production and release;

- water quality (nutrient levels, $\mathrm{pH}, \mathrm{DOC}$ etc.);

- temperature.

Dreyfus et al. (2016) and Pestana et al. (2016) reported an unexpected additional risk associated with the storage and treatment of cyanobacteriaimpacted sludge: these authors conducted a series of experiments, using cultured and environmental cyanobacteria, designed to simulate a sludge treatment lagoon. Within the closed systems containing cyanobacterialaden sludge and supernatant, they reported an up to 2.8 -fold increase of total metabolite concentration (MIB [2-methylisoborneol], geosmin and cyanotoxin concentration) over a period of 2-7 days. They attributed the increase to cell multiplication in the sludge or supernatant, increased metabolite production due to stress or a combination of both factors.

The findings of this research and previous literature show that, in a static (batch) system

- Cyanobacteria, once captured in the sludge, will generally begin to lyse within 0-2 days.

- Some cells will remain viable in the sludge, and the maximum release of toxins (indicative of total cell death and lysis) may take up to several weeks.

- The toxins released may represent up to 2.8 times the initial mass in the closed system.

- The time taken for the biodegradation of the toxins to half the observed maximum concentration may be a week or longer, depending on the toxin and the environmental conditions.

As a result, it is not possible to assess the risk posed by the reuse of sludge and sludge supernatant, and the assumption should be that the toxin 
concentration in the supernatant water may remain high for time spans of several weeks rather than days.

\subsubsection{Membrane filtration}

Most cyanobacterial cells and/or filaments or colonies are $2 \mu \mathrm{m}$ in size or larger; therefore, membranes with a pore size smaller than this - such as microfiltration (MF) and ultrafiltration (UF) membranes - will remove the cells. However, a prior coagulation step is generally used in the application of membranes for water treatment, and the presence of cyanobacteria is likely to result in a rapid increase in transmembrane pressure (Dixon et al., 2012). The risk associated with any filtration process is damage to the cells and release of cell-bound toxin, which would not be removed by these membranes. In practice, some removal of dissolved toxins has been noted by MF and UF; however, this is most likely due to the adsorption of the cyanotoxins onto the membrane surface, which would decrease significantly with time as the adsorption sites are occupied by the toxin molecules (Chow et al., 1997; Dixon et al., 2012).

The extent of any damage to the cells will depend on operating parameters such as the flux through the membranes, pressure and the time period between backwashes. While some laboratory studies have shown that the cells are not damaged during filtration (Chow et al., 1997; GijsbertsenAbrahamse et al., 2006), full-scale data from a submerged UF membrane plant in South Australia suggest that the accumulation of floc in the membrane tank leads to metabolite release over time (unpublished data).

\subsubsection{Assessing the risk of toxin release and breakthrough of cyanobacteria and cell-bound toxins}

Checklist 10.1 outlines information needed to assess how effectively cyanobacterial cells can be removed intact without toxin release by optimising treatment; the higher the number of affirmative answers, the greater the likelihood of successful cyanobacteria removal. Adaptation of processes to specific local conditions is useful. Treatment plant operators will typically have the expertise and information needed for this assessment.

\section{CHECKLIST I0.I: COLLECTING INFORMATION ON THE EFFICACY OF REMOVAL OF CYANOBACTERIA AND CELL-BOUND TOXINS}

- Is data from cyanobacteria monitoring in the source water available at sufficiently regular time intervals to adapt treatment (e.g., fortnightly or weekly during seasons with likely occurrence)? 
- Can pre-oxidation processes be suspended during a cyanobacterial bloom until the danger of release of dissolved toxins has passed?

- Are physical barriers optimised (such as coagulation/flocculation or membrane filtration) to achieve optimum particle and dissolved organic carbon (DOC) removal?

- Are treatment residuals removed rapidly from the system (e.g., is sludge removed from clarifiers, are filters backwashed frequently)?

- Are cyanobacterial concentrates isolated from the system (i.e., is sludge supernatant return and/or membrane backwash water return suspended during blooms)?

- Has the system been validated through measuring cyanotoxin concentrations after each of the steps in the treatment train during phases in which it is challenged with bloom material?

\section{I0.2 TREATMENT OPTIONS FOR DISSOLVED CYANOTOXINS}

Despite the measures described above, a breakthrough of cyanobacterial toxins from the initial treatment steps cannot be avoided in all cases, and a treatment for the removal of dissolved cyanotoxins needs to be considered when planning operations.

Dissolved cyanotoxins can be removed using a range of treatment processes. As the effectiveness of each process depends on the raw water quality and the concentration and type of the cyanotoxins, a multibarrier approach is important for reliable removal.

Three main categories of treatment can be applied for the removal of dissolved cyanotoxins: physical, chemical and biological processes. Physical processes include adsorption and membrane filtration; chemical processes include oxidation by chlorine, ozone or other oxidants; and biological processes employ microorganisms fixed in biofilms, particularly on sand or other media used for filtration (rapid or slow), on granular activated carbon (GAC), or on sediment particles in slow sand filtration or bank filtration (see Chapter 8).

\subsection{Physical processes}

\subsection{I.I Adsorption}

\section{Powdered activated carbon}

Powdered activated carbon (PAC) is a fine carbonaceous adsorbent with a high surface area (typically $800-1200 \mathrm{~m}^{2} / \mathrm{g}$ ) that can effectively remove a range of organic contaminants from water. As a treatment for dissolved cyanotoxins, it has the advantage that it can be dosed only when required, and at a range of concentrations. The most effective point for the addition 
of PAC is prior to coagulation to allow a contact time where the adsorbent is well dispersed and mixed before it is removed during the coagulation process. If this is not possible, PAC may be added with, or after, the coagulant and it will still achieve some removal.

There are many PACs commercially available; they vary in their properties according to the raw material from which they are produced (e.g., coal/anthracite, coconut shell or wood) and their mode and extent of activation. They will also vary in terms of effectiveness and cost. Other important things to note are that individual toxin variants will adsorb to different extents; for example, for MCs, the order of removal efficiency is MC-RR>MC-YR>MC-LR>MC-LA (Newcombe et al., 2003; He et al., 2017), and the efficiency of a particular carbon for a particular toxin will depend on the number and size of the adsorption sites, or pores, in the PAC. In addition, other DOC components compete for adsorption sites and will reduce the removal of cyanotoxins (Figure 10.1).

(a)
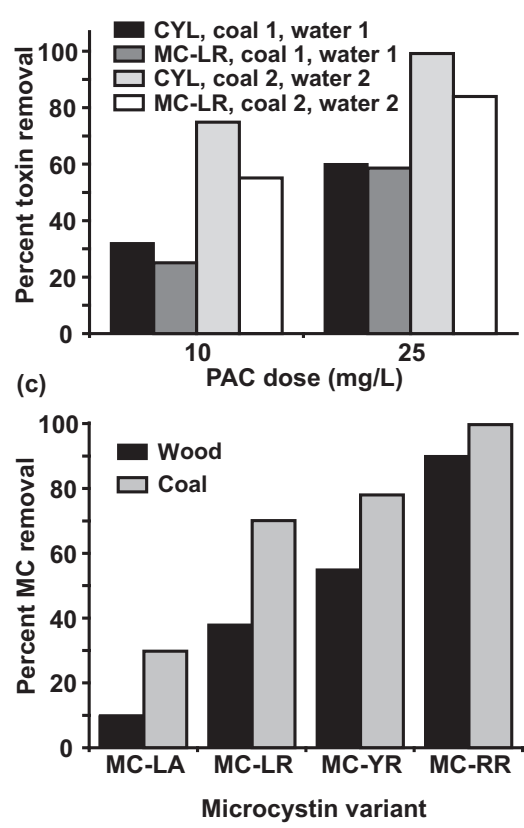

(b)
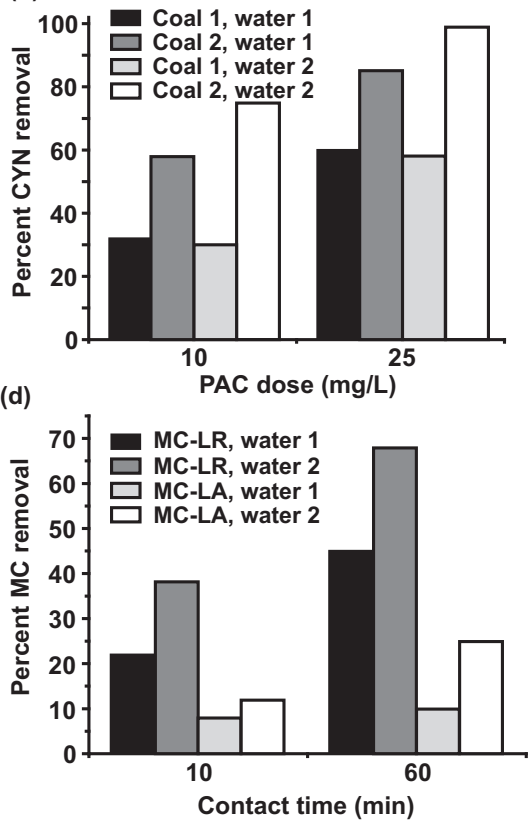

Figure 10.I Examples of the effect of different factors in the application of PAC on cyanotoxin removal effectiveness. Coal - coal-based PAC; wood - wood-based PAC; water I - DOC = $10 \mathrm{mg} / \mathrm{L}$; water $2-D O C=5 \mathrm{mg} / \mathrm{L}$. (a) Effect of toxin, PAC, DOC and dose; (b) Effect of DOC, PAC and dose; (c) Effect of PAC and $M C$ variant; (d) Effect of MC variant, DOC and contact time. (Adapted from Newcombe \& Nicholson, 2004; Cook \& Newcombe, 2008; and Ho et al., 2008; Ho et al., 20II; with unpublished data.) 
In summary, the major factors controlling the removal efficiency of cyanotoxins by PAC are as follows:

- type of cyanotoxin;

- type of PAC (raw material, manufacturing method, particle size);

- PAC dose;

- point of application;

- contact times;

- DOC concentration and characteristics.

Figure 10.1a-d demonstrates the significant differences in removals that are observed as a result of these factors - removal can range between $10 \%$ and close to $100 \%$ between cyanotoxins and the type of PAC that is used.

Table 10.2 presents a summary of some of the literature related to the application of PAC for the removal of cyanotoxins. Only very limited data are available for anatoxin-a (Vlad et al., 2014). As there is such a variety of factors influencing the effective application of PAC and the factors mentioned above will vary between water supplies, the information given in Figure 10.1 and Table 10.2 can only serve as a starting point for assessing which type of powdered activated carbon (PAC) to use in a given water supply system challenged by toxic cyanobacterial blooms.

Therefore, it is important to undertake testing to identify the most effective PAC for each treatment plant. Some simple processes for PAC testing are described by Newcombe et al. (2010). Another valuable resource to facilitate the appropriate choice of PAC and estimation of dose requirements at a particular site is the American Water Works Association's (AWWA) "PAC Calculator for Cyanotoxin Removal and Cyanotoxin Jar Testing Protocols". This tool can be downloaded from the AWWA website (http://www.awwa.org/resources-tools/water-knowledge/cyanotoxins. aspx; a login and password are required).

\section{Granular activated carbon (GAC)}

GAC has a larger particle size than powdered activated carbon (PAC) and is employed either as a filter medium, in place of conventional rapid filtration media, or, more commonly, as a final polishing step.

New (virgin) GAC is extremely effective for the removal of microcystins, saxitoxins and anatoxin-a (UKWIR, 1996; Newcombe et al., 2003; Ho \& Newcombe, 2007; Capelo-Neto \& Buarque, 2016); however, continuous adsorption of DOC (DOC preloading) reduces the adsorption capacity of a GAC filter for cyanotoxins and consequently reduces its operational lifetime. For example, virgin GAC removes cyanotoxins to below the detection limit in most cases, while after several months of operation, significant breakthrough usually occurs (Craig \& Bailey, 


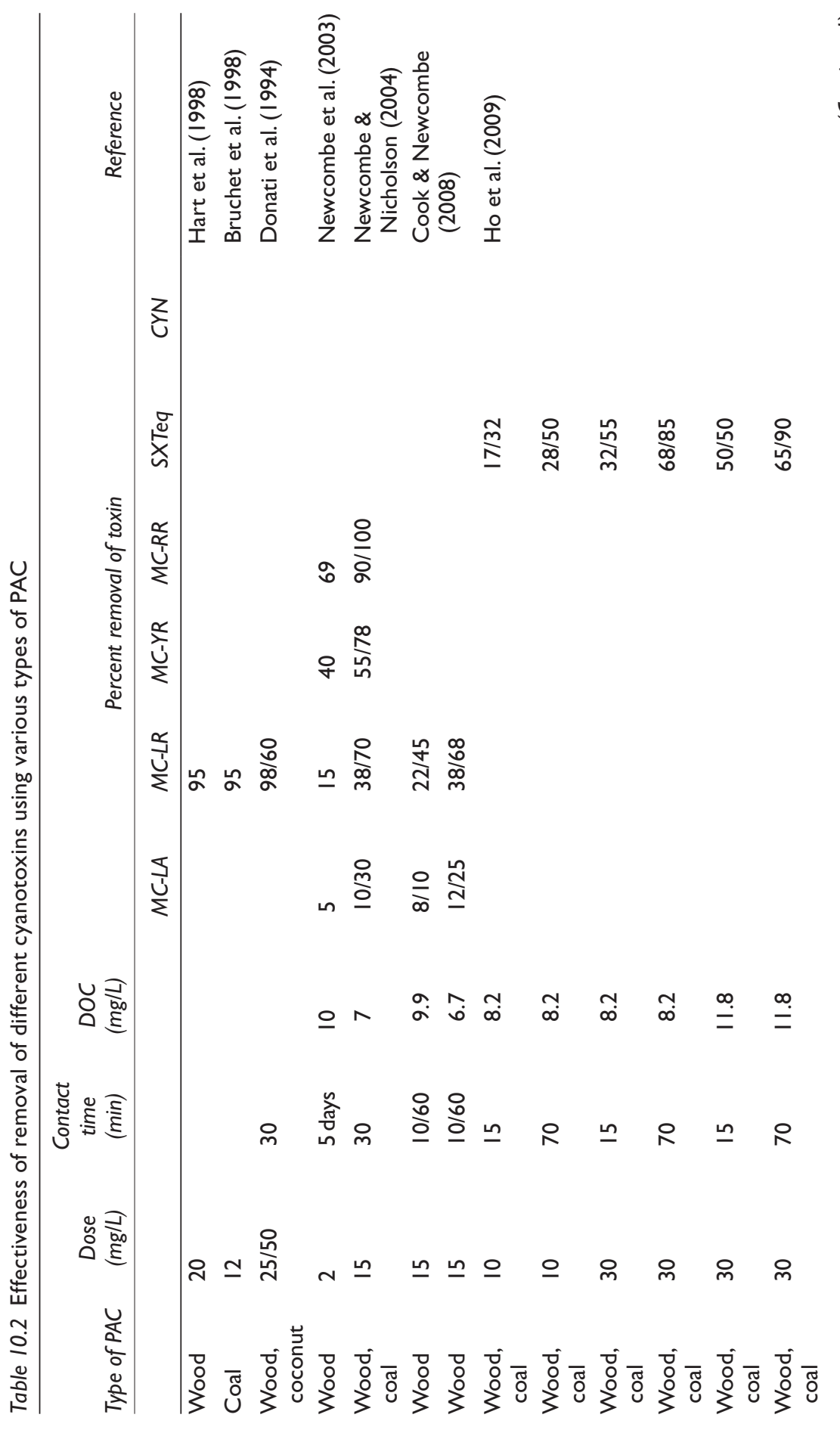




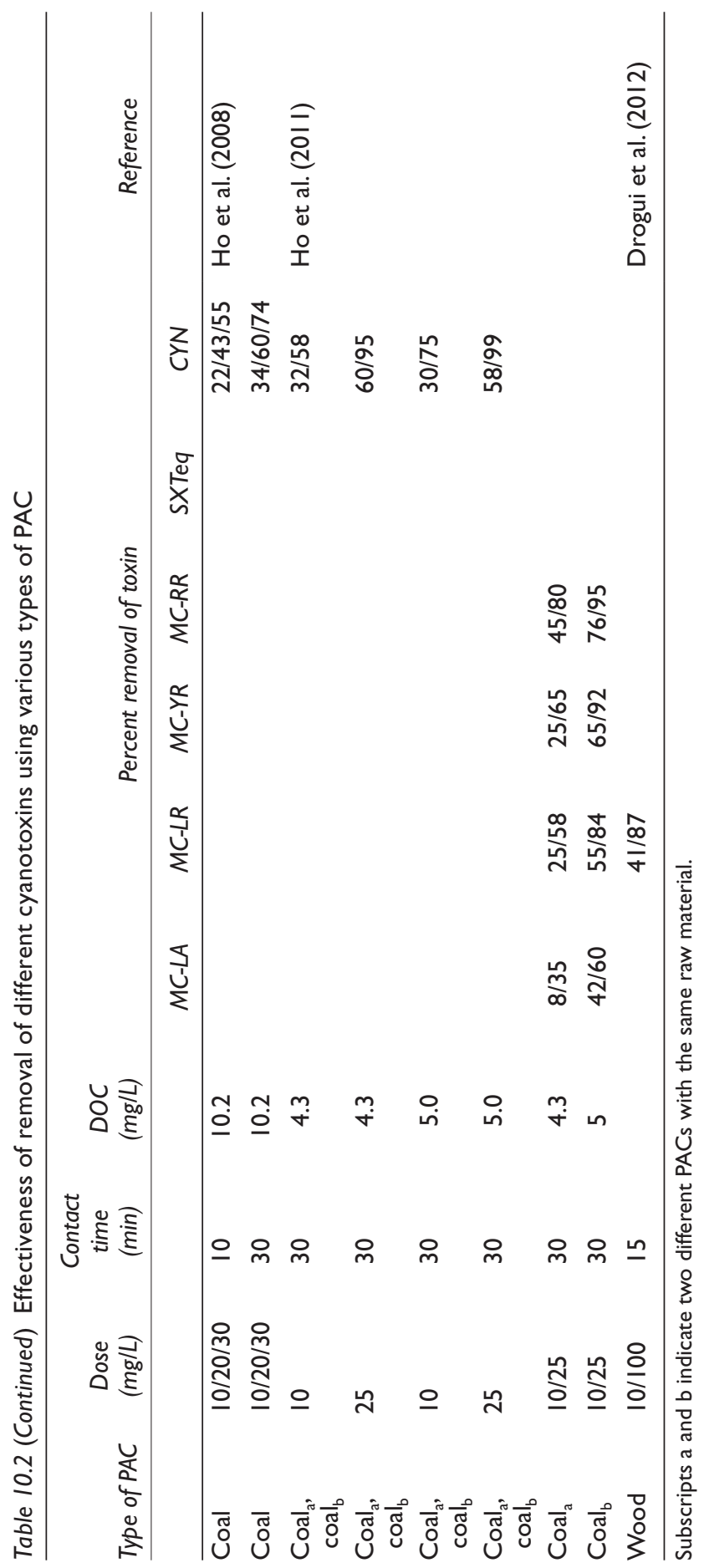


1995; Ho \& Newcombe, 2007). Where no breakthrough is observed after 6 months' operation, the removal has been attributed to a combination of adsorption and biodegradation by biofilms established on the filter (UKWIR, 1996; Wang et al., 2007). There is an abundance of literature describing methods that may be used for the prediction of the lifetime of GAC filters for the removal of organic contaminants (e.g., Capelo-Neto \& Buarque, 2016; Kennedy et al., 2017). In practice, it is very difficult to predict when the GAC filter may no longer provide a sufficient barrier for dissolved cyanotoxins. Therefore, it is recommended that if GAC is a major barrier within the plant, it is tested on a regular basis to demonstrate that it will be effective in the event of a toxin challenge. This can be accomplished by

1. full-scale investigative sampling through the plant during a cyanotoxin challenge (see section 9.7) and/or by

2. laboratory testing, accomplished through small-scale column trials with plant water spiked with the cyanotoxin(s) of interest (Sawade et al., 2012).

Laboratory testing also helps to determine whether any of the removal is due to biological degradation on the GAC. This can inform the operation of the filter; for example, if the majority of the removal is due to biological activity, the filter should be maintained as a biofilter (no disinfectant in the backwash water or influent to the filter) and the replacement of the GAC can be postponed.

The removal of cyanotoxins is also affected by the flow rate through the filter, in particular the empty bed contact time (EBCT, the length of time it takes for the volume of water equivalent to the filter volume to pass through). The longer the contact time, the more effective the removal, with an EBCT of $10-15$ min considered to be optimal.

The major influences on the effectiveness of GAC for the removal of toxins are as follows:

- type of GAC;

- length of time since commissioning (dissolved organic carbon [DOC] loading time);

- EBCT;

- biological activity resulting in biodegradation.

Ozone can be used as a pretreatment step to granular activated carbon (GAC). The combined process is extremely effective as cyanotoxins are susceptible to ozonation (see following sections) and the GAC can remove any oxidation by-products that are formed. 


\section{Other adsorbents}

While activated carbon is the most common adsorbent in use for the removal of cyanotoxins, the potential of novel adsorbents to remove cyanotoxins in particular for the removal of microcystins - is the focus of a significant body of research. Table 10.3 summarises some of the findings for a range of studies on the adsorption of MC-LR onto these materials.

\subsection{I.2 Membrane filtration}

Membranes such as microfiltration (MF) and ultrafiltration (UF) have a pore range larger than the size of cyanotoxin molecules in solution so they are not an effective measure for the removal of dissolved cyanotoxins. Pore sizes of nanofiltration $(\mathrm{NF})$ and reverse osmosis $(\mathrm{RO})$ membranes do span the size of the cyanotoxin molecules; however, the rejection of the various toxins by these membranes is dependent on the molecular weight cut-off (MWCO) and the surface chemistry of the membrane as well as the relationship between these factors and the size and chemical characteristics (such as polarity, charge and hydrophilicity) of the toxins. That is, some NF or RO membranes will be effective, but others may be only partially effective for particular cyanotoxins (Gijsbertsen-Abrahamse et al., 2006; Teixeira \& Rosa, 2006b; Dixon et al., 2012). In summary, it is expected that dissolved toxins would be rejected by RO membranes and NF membranes with a pore size distribution in the lower range in most cases. However, some membranes may allow smaller toxin molecules, like anatoxin-a, to permeate the membrane.

Table 10.3 Adsorption capacities of novel adsorbents for the adsorption of MC-LR

\begin{tabular}{|c|c|c|}
\hline Adsorbent & Capacity (mg/g) & Reference \\
\hline Activated carbon fibres & 17.0 & Pyo \& Moon (2005) \\
\hline Iron oxide nanoparticles & 0.7 & Lee \& Walker (20II) \\
\hline Magnetic macroporous silica & $3.3 \times 10^{-3}$ & Liu et al. $(2010)$ \\
\hline $\mathrm{Fe}_{3} \mathrm{O}_{4} @ \mathrm{CSNT}$ & 0.5 & Chen et al. (2009) \\
\hline Magnetic core mesoporous shell & 20.0 & Deng et al. (2008) \\
\hline Microgel-Fe(III) & 164.5 & Dai et al. (20I2) \\
\hline HP20 resin & 3.3 & Zhao et al. $(20 / 3)$ \\
\hline Peat & 0.3 & Sathishkumar et al. (20I0) \\
\hline $\mathrm{Fe}_{3} \mathrm{O}_{4} @ \mathrm{Al}-\mathrm{B}$ & 161.3 & Lian et al. $(2014)$ \\
\hline Graphene oxide & 1.7 & Pavagadhi et al. (20I3) \\
\hline Magnetophoretic polypyrrole nanoparticles & 160 & Hena et al. (2016) \\
\hline $\mathrm{KOH}$-activated semicoke & 8430 & Chen et al. (20I5) \\
\hline $\mathrm{HNO}_{3}$-activated semicoke & 4276 & \\
\hline PAM/SA-MMT a & 32.7 & Wang et al. (20I5) \\
\hline
\end{tabular}

Source: Adapted from Lian et al. (2014).

a Polyacrylamide/sodium alginate montmorillonite. 


\subsubsection{Chemical processes}

\subsubsection{Chlorine}

Chlorine has been demonstrated to be an effective oxidant for the destruction of microcystins, saxitoxins and cylindrospermopsin (e.g., Senogles et al., 2000; Acero et al., 2005; Merel et al., 2010), but not for anatoxin-a (Carlile, 1994; Rodriguez et al., 2007b).

The doses required for oxidation of the toxins to below the treatment goal, or the relevant guideline or regulatory value, depend on the conditions at the point of chlorination, which are as follows:

- DOC concentration and characteristics;

- the concentration of any other contaminant that may exert a chlorine demand such as ammonium, iron and manganese;

- reaction time and residual chlorine concentration;

- temperature;

- $\mathrm{pH}$.

The most important criterion for the successful chlorination of toxins is the application of the dose required to overcome the chlorine demand and have sufficient residual chlorine to allow effective oxidation to occur. As this will vary depending on the chemical water characteristics, it is useful to use the concept of chlorine exposure, or CT, the chlorine concentration integrated over the reaction time, given in units of $(\mathrm{mg} \times \mathrm{min}) / \mathrm{L}$.

The $\mathrm{pH}$ has a significant effect on the reaction of chlorine with cyanotoxins as hypochlorous acid $(\mathrm{HOCl})$ is a stronger oxidant than the hypochlorite ion $\left(\mathrm{ClO}^{-}\right)$, which is the major species of chlorine present at $\mathrm{pH}$ values above 7.5. In addition, $\mathrm{pH}$ can affect the degree of protonation of cyanotoxins, which may in turn affect their reactivity (Ho et al., 2006). The effect of $\mathrm{pH}$ on the chlorination of toxins is most likely a combination of both factors.

Table 10.4 summarises some of the literature relating to the chlorination of cyanotoxins under specific conditions. Anatoxin-a is not included as chlorination would not be recommended as a barrier for this cyanotoxin (Carlile, 1994; Rodríguez et al., 2007).

In summary, the susceptibility of individual microcystin congeners to chlorination was found to be (Ho et al., 2006):

$$
\text { MC-YR > MC-RR > MC-LR > MC-LA }
$$

and that of the most common cyanotoxins (Rodríguez et al., 2007):

$$
\text { CYN }>\text { MC-LR } \gg \text { ATX. }
$$

It is important to note that the CT values and toxin oxidation values given in Table 10.4 are based on laboratory experiments only. It is recommended that caution be applied when considering chlorine as a major barrier, as the limited 
Table 10.4 Contact time (CT) values for chlorination of cyanotoxins ( $\mathrm{mg} \mathrm{min} / \mathrm{L})(\mathrm{d})-\mathrm{Cl}_{2}$ dose $\mathrm{mg} / \mathrm{L}$

\begin{tabular}{ccc}
\hline $\mathrm{pH}$ & $\mathrm{pH}$ & $\mathrm{pH}$ \\
$6-6.9$ & $7-7.9$ & $8-8.9$ \\
\hline
\end{tabular}

Toxin, water quality

CT values for $95-100 \%$ oxidation

\begin{tabular}{|c|c|c|c|c|}
\hline MC-LR Reagent water $10^{\circ} \mathrm{C}$ & 47 & 68 & 187 & Acero et al. (2005) \\
\hline MC-LR Reagent water $20^{\circ} \mathrm{C}$ & 35 & 51 & 140 & \\
\hline MC-LR Reagent water $10^{\circ} \mathrm{C}$ & 46 & 220 & & Xagoraraki et al. (2006) \\
\hline CYN DOC $=0$ & & 30 & & Senogles et al. (2000) \\
\hline$C Y N, D O C=3.0 / 4.1$ & & 2,2 & & Ho et al. (2008) \\
\hline CYN, DOC $=5$ & & $1.5(d)^{a}$ & & Rodriguez et al. (2007c) \\
\hline $\mathrm{SXT}_{\mathrm{eq}} \mathrm{DOC}=2.7$ & & 20 & 20 & Ho et al. (2009) \\
\hline \multicolumn{5}{|l|}{ CT values for $90-95 \%$ oxidation } \\
\hline MC-LR Reagent water $10^{\circ} \mathrm{C}$ & 27 & 40 & 110 & Acero et al. (2005) \\
\hline MC-LR Reagent water $20^{\circ} \mathrm{C}$ & 21 & 30 & 82 & \\
\hline MC-LR, DOC $=2.9$ & & 20 & & Ho et al. (2006) \\
\hline MC-YR, DOC $=2.9$ & & $<1$ & & \\
\hline$M C-Y R, D O C=5.0$ & 1 & & & \\
\hline$M C-R R, D O C=2.9$ & & 7 & & \\
\hline$M C-R R, D O C=5.0$ & 3 & & & \\
\hline$C Y N, D O C=3.6$ & & & $I(d) b$ & Rodríguez et al. (2007) \\
\hline \multicolumn{5}{|l|}{ CT values for $75-90 \%$ oxidation } \\
\hline MC-LR, coagulated water, $12^{\circ} \mathrm{C}$ & & 65 & & Xagoraraki et al. (2006) \\
\hline$S \times T_{e q} D O C=5 . I$ & & 20 & 20 & Ho et al. (2009) \\
\hline \multicolumn{5}{|l|}{ CT values for $50-75 \%$ oxidation } \\
\hline MC-LR, DOC $=5.0$ & 4 & & & Ho et al. (2006) \\
\hline$M C-Y R, D O C=5.0$ & $<1$ & & & \\
\hline MC-LA, DOC $=2.9$ & & 15 & & \\
\hline$M C-L A, D O C=5.0$ & 4 & & & \\
\hline MC-LR, DOC = 3.6 & & & $2(d)$ & Rodríguez et al. (2007) \\
\hline $\mathrm{CYN}, \mathrm{DOC}=3.6$ & & & $0.8(d)^{b}$ & \\
\hline MC-LR Reagent water $11^{\circ} \mathrm{C}$ & 11 & 51 & & Xagoraraki et al. (2006) \\
\hline
\end{tabular}

a $\mathrm{Cl}_{2}$ demand met.

b $\mathrm{Cl}_{2}$ demand not met.

literature describing full-scale chlorination of cyanotoxins suggests that these CT values may not be sufficient to achieve the desired results in the presence of a natural bloom (Zamyadi et al., 2012b; Mohamed et al., 2015; Mohamed, 2016). A potential issue with applying laboratory-based chlorination results to the full scale was outlined by Acero et al. (2005). These authors reported CT 
values for the oxidation of microcystins in batch experiments representing an ideal plug-flow reactor (PFR). Chlorination at the full scale does not take place under ideal flow conditions, and the authors suggested it would be better represented by a hybrid PFR and completely stirred tank reactor (CSTR) model. They described the two types of reactors as the most and least effective, respectively, and as a result, the laboratory-based experiments may underestimate the actual required CT by up to an order of magnitude (Acero et al., 2005).

Based on guidelines presented by the US EPA (US EPA, 2010), Stanford et al. (2016) also discussed the effect of nonideal conditions that may influence the application of oxidation data obtained from an ideal configuration and calculated the effect on percent oxidation of MC-LR by chlorine. They determined that the effective CT in the nonideal situation could be about one-third of that in an ideal reactor, and the removal of MC-LR could be approximately half the expected value. Therefore, it is recommended that CT values substantially higher than those suggested by laboratory data be applied at the full scale.

It is also important to note that the efficiency of chlorination is dependent on the chemical characteristics of the water at the chlorination point; for example, turbidity in filtered water $>0.3$ nephelometric turbidity units (NTU) could not only be an indicator of reduced filtration efficiency but also may reduce the effective chlorine $\mathrm{CT}$ for both toxin oxidation and disinfection (WHO, 2017).

\subsubsection{Ozone}

Ozone has been found to be a very effective oxidant for the destruction of dissolved cyanotoxins provided a residual is present (Rositano et al., 2001; Shaw wa \& Smith, 2001). Rodríguez et al. (2007) showed ozone to be effective for the elimination of a range of cyanotoxins and determined that the order of ease of oxidation followed the trend: MC-LR $>$ CYN $>$ ATX, while Rositano et al. (2001) reported a trend of MC-LR and MC-LA $>$ ATX $>$ STX.

As with chlorine, the doses required for ozonation of the toxins to below the treatment target, guideline value or regulation depend on the conditions at the point of ozonation, which are as follows:

- dissolved organic carbon (DOC) concentration and characteristics;

- reaction time and ozone concentration;

- temperature;

- $\mathrm{pH}$.

In the case of ozone, other water quality parameters like alkalinity may also play a role as the carbonate ion can act as an inhibitor of the reaction by scavenging the hydroxyl radical, the major reactant for the oxidation of organic micropollutants by ozone (Ho et al., 2004).

Table 10.5 summarises some of the literature relating to the ozonation of cyanotoxins under specific conditions. 


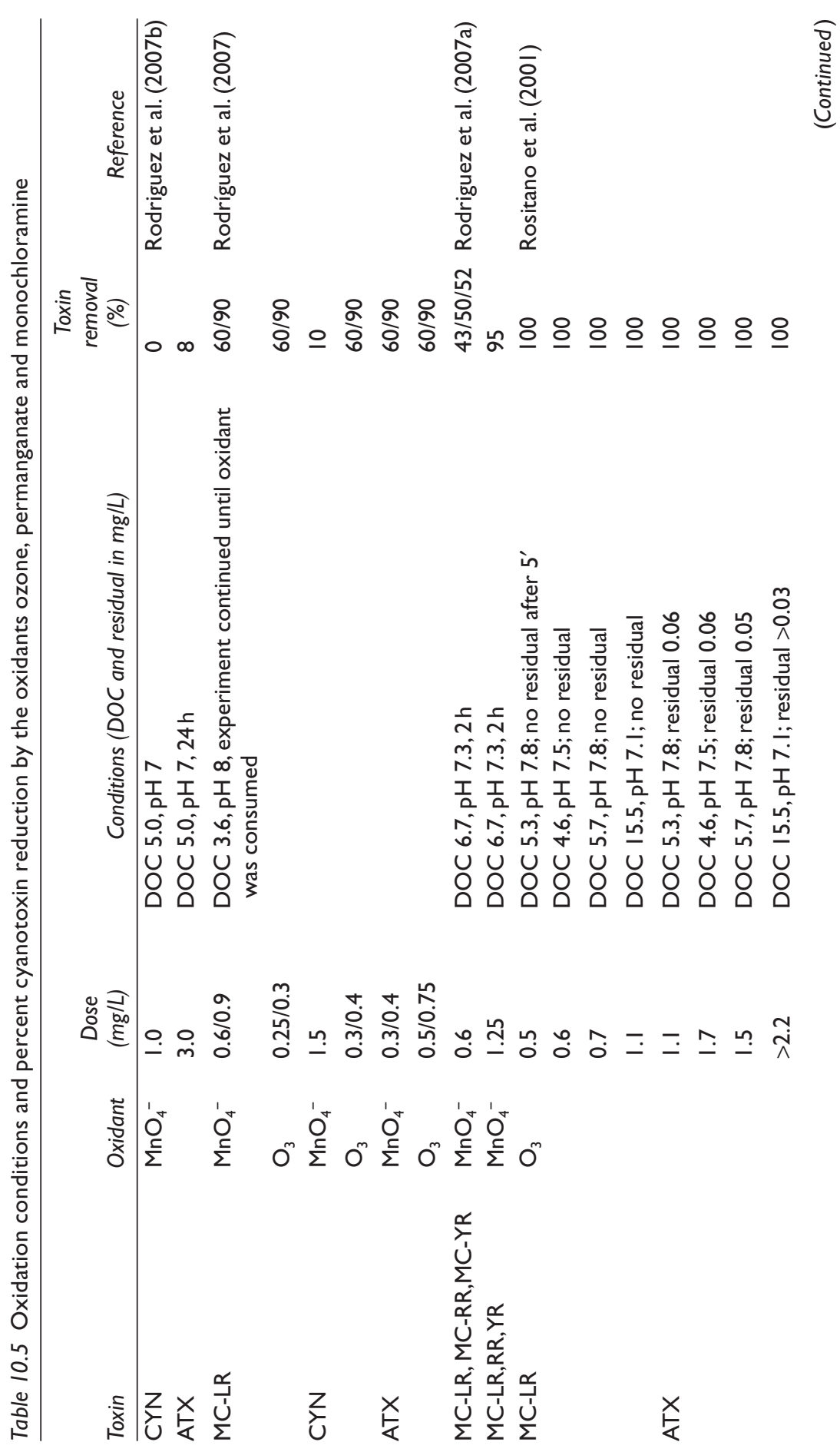




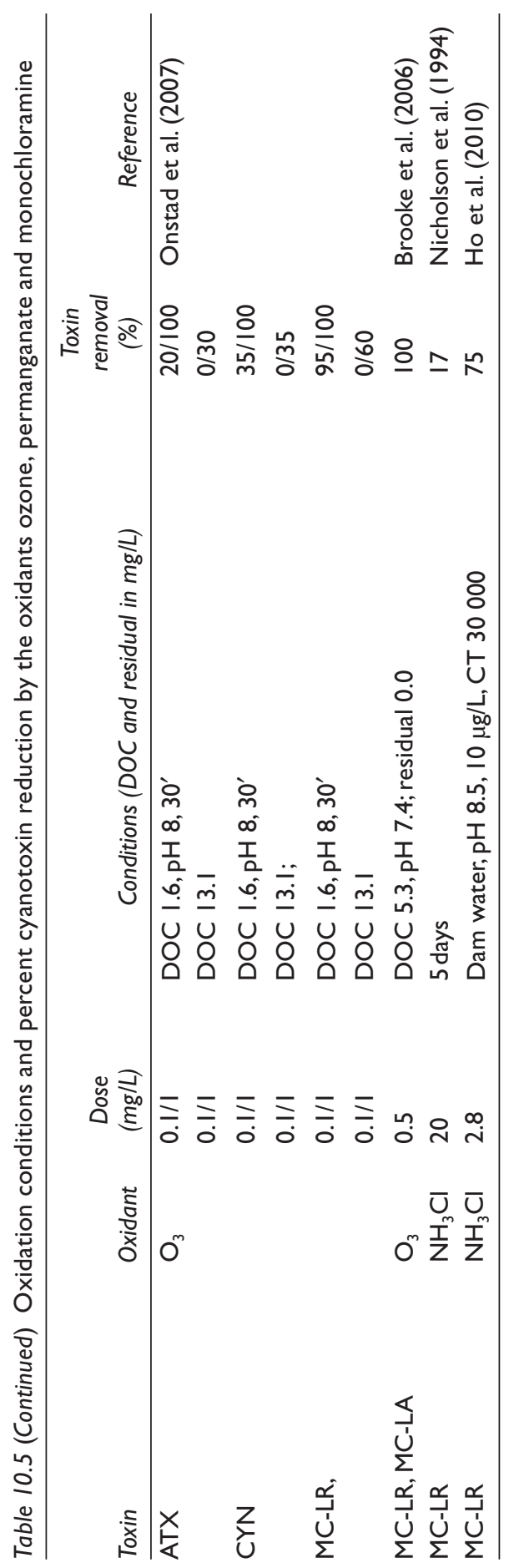




\subsubsection{Other oxidants}

Chloramine and chlorine dioxide have been shown to be ineffective oxidants for cyanotoxins at CT values normally used in water treatment operations (Rodríguez et al., 2007; Ho et al., 2010).

Potassium permanganate has been reported to oxidise microcystins, anatoxin-a and cylindrospermopsin (Carlile, 1994; Rodriguez et al., 2007a; Rodríguez et al., 2007; Rodriguez et al., 2007b) showed slightly higher permanganate reactivity with MC-RR and MC-YR compared to MC-LR. This is in agreement with the order of oxidation of the microcystins by chlorine (MC-YR $>$ MC-RR > MC-LR > MC-LA) reported by Ho et al. (2006). Although the dose required will be dependent on water chemistry, most studies found a dose of $1-2 \mathrm{mg} / \mathrm{L}$ to be very effective.

Table 10.5 summarises some of the literature relating to the use of the more common alternative oxidants for the oxidation of cyanotoxins under specific conditions.

Stanford et al. (2016) describe a tool designed to aid in the application of chlorine, monochlorine, ozone, chlorine dioxide and potassium permanganate for the oxidation of dissolved cyanotoxins (Hazen-Adams Cyanotoxin Tool for Oxidation Kinetics, CyanoTOX). This tool can be downloaded from the website of the American Water Works Association (AWWA, 2019). This tool is based on user-defined oxidant decay curves and desired final toxin concentrations, and nonideal plug flow is taken into account by the use of the baffling factor suggested by the US EPA for disinfection (US EPA, 2010).

In general, UV irradiation, as applied for disinfection of drinking-water, cannot be regarded as a practical method for an effective toxin removal. However, the combination of UV irradiation and catalysts such as hydrogen peroxide and titanium dioxide can be very effective for the destruction of dissolved toxins. These processes, and others that rely on the formation of hydroxyl radicals for the oxidation of chemical contaminants, are referred to as advanced oxidation processes (AOPs). A range of AOPs has been the focus of more recent research. In most cases, oxidation is very effective, but each process depends on the type and concentration of the catalyst, the chemical characteristics of the water and the type of toxin. The application of these processes is therefore very site and process specific. Table 10.6 presents some of the advanced oxidation techniques that have been studied for the destruction of cyanotoxins.

Although advanced oxidation techniques have been shown to be extremely effective at the laboratory scale, their use is very limited at the full scale; therefore, validation as an effective barrier to cyanotoxins is not possible at the time of the publication of this book. One example of AOP application at the full scale is the dosing of hydrogen peroxide or chlorine prior to UV disinfection. As UV irradiation is becoming more common in drinking-water treatment plants as an effective barrier against pathogens, a cost-effective option for some water utilities could be to provide an AOP barrier for organic micropollutants. As technology and cost-effectiveness improves, these processes may become more widespread. 
Table 10.6 Advanced oxidation processes that have been studied for the destruction of cyanotoxins

\begin{tabular}{|c|c|c|}
\hline Toxin & Advanced Oxidation Process (AOP) & Reference \\
\hline MC-LR & $\mathrm{UV} / \mathrm{TiO}_{2}$ & Feitz et al. (1999) \\
\hline MC-LR & $\mathrm{TiO}_{2} / \mathrm{H}_{2} \mathrm{O}_{2}$ & Cornish et al. (2000) \\
\hline CYN & $\mathrm{UV} / \mathrm{TiO}_{2}$ & Senogles et al. (200I) \\
\hline MC-LR & $\mathrm{UV} / \mathrm{TiO}_{2}$ & $\begin{array}{l}\text { Shephard et al. } \\
(2002)\end{array}$ \\
\hline MC-LR & $\mathrm{UV} / \mathrm{TiO}_{2}, \mathrm{UV} / \mathrm{TiO}_{2} / \mathrm{H}_{2} \mathrm{O}_{2}, \mathrm{UV} / \mathrm{H}_{2} \mathrm{O}_{2}$ & Liu et al. (2002) \\
\hline MC-LR & $\mathrm{UV} / \mathrm{TiO}_{2}$ & Liu et al. (2003) \\
\hline MC-LR & $\mathrm{O}_{3} / \mathrm{H}_{2} \mathrm{O}_{2}, \mathrm{O}_{3} / \mathrm{Fe}(\mathrm{II})$, and Fenton oxidation & $\begin{array}{l}\text { Al Momani et al. } \\
(2008)\end{array}$ \\
\hline MC-LR & $\mathrm{UV} / \mathrm{S}_{2} \mathrm{O}_{8}{ }^{2-}$ & $\begin{array}{l}\text { Antoniou et al. } \\
(2010)\end{array}$ \\
\hline MC-LR & $\mathrm{UV} / \mathrm{O}_{3}$ & Liu et al. $(2010)$ \\
\hline CYN & $\mathrm{UV} / \mathrm{O}_{3}$ & Song et al. (2012) \\
\hline CYN & $\mathrm{UV} / \mathrm{H}_{2} \mathrm{O}_{2}$ & He et al. (20I4) \\
\hline MC-LR, CYN & Solar irradiation $/ \mathrm{TiO}_{2}$ nanoparticles & Pinho et al. (2015) \\
\hline MCs & $\mathrm{UV} / \mathrm{H}_{2} \mathrm{O}_{2}, \mathrm{UV} / \mathrm{S}_{2} \mathrm{O}_{8}{ }^{2-}$ and $\mathrm{UV} / \mathrm{HSO}_{5}{ }^{-}$ & He et al. (20I5) \\
\hline MCs & Simulated sunlight $/ \mathrm{H}_{2} \mathrm{O}_{2}$ & Huo et al. (2015) \\
\hline MCs & Photoelectrooxidation - electrical current/UV & Garcia et al. (20I5) \\
\hline MCs & $\mathrm{UV} /$ microbubble $\mathrm{O}_{3}$ & Zhu et al. (20I5) \\
\hline MC-LR & Chlorine/UV & Zhang et al. (2016) \\
\hline MC-LR, CYN & Visible-UV/carbon-doped $\mathrm{TiO}_{2}$ & Fotiou et al. $(2016)$ \\
\hline MCs, NOD & UV/TiO ${ }_{2}$-coated glass spheres & Pestana et al. (20I5) \\
\hline CYN & Ozone $/ \mathrm{TiO}_{2}$ & Wu et al. (2015) \\
\hline CYN & $\begin{array}{l}\text { Anatase-brookite heterojunction } \\
\mathrm{TiO}_{2} / \text { visible-UV }\end{array}$ & $\begin{array}{l}\text { El-Sheikh et al. } \\
(2017)\end{array}$ \\
\hline MC-LR & $\mathrm{TiO}_{2}$-coated carbon electrodes & Lobón et al. (2017) \\
\hline MC-LR & $\begin{array}{l}\text { Sulphur }(\mathrm{S}) \text {, nitrogen }(\mathrm{N}) \text {, and carbon } \\
\text { (C)-codoped } \mathrm{TiO}_{2} \text { nanoparticles }\end{array}$ & Zhang et al. (20|4) \\
\hline MC-LR & Copper oxide-coated activated carbon & $\begin{array}{l}\text { Karthikeyan et al. } \\
(2016)\end{array}$ \\
\hline MCs & Cold plasma and UV with $\mathrm{TiO}_{2}$ coating & Jiang et al. (2017) \\
\hline
\end{tabular}

\subsubsection{By-product formation}

Chemical oxidation of organic compounds may form a range of by-products. In practice, when the oxidation of cyanotoxins takes place, a complex mixture of other organic compounds, such as DOC or natural organic matter (NOM), is also present (particularly in bloom situations) and will be oxidised simultaneously. As a consequence, many different types of byproducts will be formed, some of which may be potentially harmful at high concentrations. In fact, many by-products of oxidation of NOM are currently unknown, so identifying the individual by-products of cyanotoxin 
oxidation separately from those produced from the oxidation of NOM is a difficult exercise. It is particularly problematic as other forms of DOC will be present at concentrations two or more orders of magnitude higher than the cyanotoxins. Table 10.7 presents some of the common disinfection byproducts (DBPs) that have been identified after the oxidation of cyanotoxins and/or cyanobacteria.

Table 10.7 Overview of studies on the generation of disinfection by-products (DBPs) and changes in toxicity after oxidation of cyanobacterial cells and specific cyanotoxins

\begin{tabular}{|c|c|c|c|c|c|}
\hline Toxin/cyanobacteria & Oxidant & $\begin{array}{c}\text { Presence } \\
\text { of NOM } \\
\text { (YIN) }\end{array}$ & $\begin{array}{l}\text { "Standard" } \\
\text { DBPs }\end{array}$ & $\begin{array}{c}\text { Reduced } \\
\text { toxicity } \\
\text { (Y/N) }\end{array}$ & Reference \\
\hline $\begin{array}{l}\text { MC-LR, MC-LA, } \\
\text { NOD }\end{array}$ & $\mathrm{Cl}_{2}$ & Y (AOM) & na & $\mathrm{Y}$ & $\begin{array}{l}\text { Nicholson } \\
\text { et al. (1994) }\end{array}$ \\
\hline MC-LR, MC-LA & $\mathrm{O}_{3}$ & Y & na & $Y$ & $\begin{array}{l}\text { Brooke } \\
\text { et al. (2006) }\end{array}$ \\
\hline CYN & $\mathrm{Cl}_{2}$ & $Y$ & THMs & n.a. & $\begin{array}{l}\text { Rodriguez } \\
\text { et al. (2007b) }\end{array}$ \\
\hline MC-LR, MC-RR & $\mathrm{MnO}_{4}^{-}, \mathrm{Cl}_{2}$ & $N, Y$ & na & $Y$ & $\begin{array}{l}\text { Rodriguez } \\
\text { et al. (2008) }\end{array}$ \\
\hline $\begin{array}{l}\text { AOM from Dol. } \\
\text { circinale }\end{array}$ & $\mathrm{Cl}_{2}$ & $Y$ & $\begin{array}{l}\text { THMs, } \\
\text { HAAs } \\
\text { NDMA }\end{array}$ & n.a. & $\begin{array}{l}\text { Zamyadi } \\
\text { et al. }(2010)\end{array}$ \\
\hline Diverse taxa & $\mathrm{Cl}_{2}$ & $Y$ & $\begin{array}{l}\text { THMs, } \\
\text { HAAs } \\
\text { NDMA }\end{array}$ & n.a. & $\begin{array}{l}\text { Zamyadi } \\
\text { et al. }(20 \mid 2 a)\end{array}$ \\
\hline Microcystis sp. & $\mathrm{Cl}_{2}$ & $\mathrm{~N}$ & THMs & n.a. & $\begin{array}{l}\text { Zamyadi } \\
\text { et al. (20|3a) }\end{array}$ \\
\hline CYN & $\mathrm{O}_{3}$ & N & na & Y & $\begin{array}{l}\text { Yan } \\
\text { et al. (2016) }\end{array}$ \\
\hline Diverse taxa & $\mathrm{O}_{3}$ & $Y(A O M)$ & $\begin{array}{l}\text { THMs, } \\
\text { HAAs }\end{array}$ & n.a. & $\begin{array}{l}\text { Zamyadi } \\
\text { et al. (2015) }\end{array}$ \\
\hline $\begin{array}{l}\text { AOM from Aph. } \\
\text { flosaquae, Ana. } \\
\text { flosaquae, } M \text {. } \\
\text { aeruginosa }\end{array}$ & $\mathrm{Cl}_{2}$ & Y (AOM) & $\begin{array}{l}\text { TCM, } \\
\text { HAAs, } \\
\text { DCAN, } \\
\text { TCNM }\end{array}$ & n.a. & $\begin{array}{l}\text { Goslan } \\
\text { et al. (2017) }\end{array}$ \\
\hline MC-LR & $\mathrm{Cl}_{2} / \mathrm{UV}$ & $\mathrm{N}$ & na & $Y$ & $\begin{array}{l}\text { Zhang } \\
\text { et al. (2016) }\end{array}$ \\
\hline Microcystis sp. & $\mathrm{Cl}_{2}$ & Y (AOM) & $\begin{array}{l}\text { TCM, } \\
\text { TCNM, } \\
\text { DCAN, } \\
\text { I, I,I,TCP, } \\
\text { I, I DCP }\end{array}$ & n.a. & $\begin{array}{l}\text { Liao } \\
\text { et al. (2015) }\end{array}$ \\
\hline MC-LR, MC-RR & $\mathrm{Cl}_{2}$ & $Y$ & na & $Y$ & $\begin{array}{l}\text { Zong } \\
\text { et al. (2015) }\end{array}$ \\
\hline
\end{tabular}


Table 10.7 (Continued) Overview of studies on the generation of disinfection by-products (DBPs) and changes in toxicity after oxidation of cyanobacterial cells and specific cyanotoxins

\begin{tabular}{llcccc}
\hline Toxin/cyanobacteria & Oxidant & $\begin{array}{c}\text { Presence } \\
\text { of NOM } \\
(\mathrm{Y} / \mathrm{N})\end{array}$ & $\begin{array}{c}\text { "Standard" } \\
\text { DBPs }\end{array}$ & $\begin{array}{c}\text { Reduced } \\
\text { toxicity } \\
(\mathrm{Y} / \mathrm{N})\end{array}$ & Reference \\
\hline MC-LR & $\mathrm{H}_{2} \mathrm{O}_{2} / \mathrm{UV}$ & $\mathrm{N}$ & na & $\mathrm{Y}$ & $\begin{array}{c}\text { Zong } \\
\text { et al. (2015) }\end{array}$ \\
CYN & $\mathrm{Cl}_{2}$ & $\mathrm{~N}$ & na & $\mathrm{Y}$ & $\begin{array}{c}\text { Merel } \\
\text { et al. (2010) }\end{array}$ \\
\hline
\end{tabular}

n.a.: not analysed; THM: trihalomethane; HAA: haloacetic acid; NDMA: nitrosodimethylamine; TCM: trichloromethane; DCAN: dichloroacetonitrile; TCNM: trichloronitromethane; DCP: dichloropropanone;AOM: intracellular (algal) organic material.

An important aspect of oxidation is whether or not it reduces the overall toxicity of a bloom. Table 10.7 also summarises some studies addressing this issue. Methods of toxicity testing have included mouse bioassay, protein phosphatase inhibition, human hepatoma cell line (HepG2), and mitochondrial and lysosomal activities measured on Caco-2 cells (see section 14.3.2). In all studies, the decrease in the concentration of the toxin due to oxidation has resulted in a decrease of toxicity, although these studies did not address genotoxicity or carcinogenicity which are also of a concern with DBPs.

Pre-oxidation during a cyanobacterial bloom may increase dissolved organic carbon (DOC) due to the release of intracellular organic material (IOMs), including cyanotoxins, which may result in increased concentrations of DBPs in the finished water. However, as discussed above, if preoxidation is avoided and cell removal through coagulation and/or filtration is optimised, the presence of cyanobacteria in the raw water should not result in a substantial increase in DBP formation.

\subsubsection{Biological filtration}

Biological filtration in drinking-water treatment occurs when a biofilm forms on granular filtration media particles such as sand, anthracite, filter coal or granular activated carbon (GAC). In the absence of a strong disinfectant residual in the inlet to the filters or the backwash water, all filter media surfaces will develop a biofilm within weeks to months, depending on the water quality. Reports in the literature describe very effective removal of cyanotoxin by biological filtration.

Microbial degradation during slow sand filtration has been reported to be very effective for the removal of microcystins (Grützmacher et al., 2002) and cylindrospermopsin (Smith et al., 2008), as has more rapid sand filtration (Wang et al., 2007; Somdee et al., 2014).

As discussed above in section 10.1, biological degradation of microcystins and anatoxin-a has also been reported in GAC filters (Carlile, 1994; Newcombe et al., 2003; Wang et al., 2007). GAC filters offer the advantage 
of two removal mechanisms, adsorption and biodegradation, and thus are an attractive treatment option for an effective cyanotoxin removal.

Biological filtration is not effective for the removal of the saxitoxins, and in one study, biological activity on an anthracite filter was shown to convert the less toxic variants to more toxic compounds, thus increasing the overall toxicity of the filtered water (Kayal et al., 2008).

Although biological filtration can be a very effective barrier, not all biological filters will remove cyanotoxins. For the removal of cyanotoxins to occur on biofilters, the following conditions are essential but not necessarily sufficient for an effective removal:

- Degrading microorganisms are present in the source water.

- They reach the filters.

- They adhere to the biofilm.

- They remain attached in the biofilm in sufficient numbers to accomplish an effective biological removal.

The type and abundance of bacteria, water chemistry, upstream treatment processes, filter media, filter contact time and hydraulic loading all have a major impact on biological filtration processes.

Perhaps the most challenging aspect of biological treatment processes is the delay for biodegradation to commence. This is often referred to as the lag period or lag phase and has been attributed to the degrading microorganisms "acclimating" or "acclimatising" to the conditions, or the numbers of degrading bacteria reaching a critical number after which degradation can be detected (see also Chapter 2). A more recent hypothesis is that bacteria may share genetic information associated with degradation, and the extent of the lag phase may depend on the copies of the genes responsible rather than the numbers of degrading bacteria (Ho et al., 2012a). Lag periods, ranging from days to more than a year, have been reported for some cyanotoxin biodegradation (Wang et al., 2007; Smith et al., 2008; Ho et al., 2012b; Somdee et al., 2014). The lag phase needs to be taken into account when planning control measures, as it may be a major hindrance for the application of biological filtration processes, particularly for the removal of contaminants that occur periodically like cyanotoxins.

In some cases, lag phases can be reduced or eliminated upon re-addition of the toxin in the filter influent, as has been shown for cylindrospermopsin (Smith et al., 2008) or MC-LR (Rapala et al., 1994; Christoffersen et al., 2002; Newcombe et al., 2003). As shown for slow sand filters in section 9.2, a filter that experiences regular toxin challenges may be more likely to display reliable removals with a reduced, or no, lag phase (Ho et al., 2012a).

If biological removal of cyanotoxins through filters within the treatment plant cannot be assured at all times, biological filtration may not be a reliable treatment barrier for the intermittent presence of cyanotoxins, and on-site validation is therefore critically important. 


\subsubsection{Assessing efficacy of treatment steps in eliminating dissolved cyanotoxins}

The checklist below outlines the information needed to assess how effectively dissolved cyanotoxins can be removed by available treatment processes and how these can be optimised. The higher the number of affirmative answers, the greater the likelihood of successful cyanotoxin removal. It may be useful to adapt this checklist to specific local conditions. More than one of the treatment options addressed is likely to be available at many treatment plants, and the more the barriers that are present, the lower the risk of cyanotoxins reaching the consumer in critical concentrations. Treatment plant operators will typically have the expertise and information needed for this assessment:

\section{CHECKLIST 10.2: COLLECTING INFORMATION ON THE EFFICACY DISSOLVED CYANOTOXIN REMOVAL}

- Are powdered activated carbon (PAC) dosing facilities in place with

- high-quality PAC, tested for the removal of cyanotoxins?

- process control to achieve a contact time of $30 \mathrm{~min}$, prior to chemical dosing? Or, if contact time is not available prior to coagulation, sufficiently higher PAC doses?

- Are granular activated filters in place with

- good-quality GAC?

- AC that has been tested regularly for an effective toxin removal and replaced when required?

- empty bed contact time $(E B C T) \geq 10 \mathrm{~min}$ ?

- Is ozone applied at a dose sufficient to maintain a residual concentration of at least $0.3 \mathrm{mg} / \mathrm{L}$ of ozone for $10 \mathrm{~min}$ ?

- Is chlorine applied at a dose sufficient to allow a CT appropriate for the raw water quality?

\subsection{SUMMARY OF TREATMENT MEASURES FOR THE REMOVAL OF CYANOBACTERIA AND ASSOCIATED CYANOTOXINS}

In summary of the discussion above, the most common, cost-effective and reliable treatment processes for removing intra- and extracellular cyanotoxins are as follows:

- physical removal of cells, intact and without damage by coagulation or membrane filtration processes;

- adsorption of dissolved cyanotoxins onto activated carbon;

- oxidation, in particular using ozone and/or chlorine. 


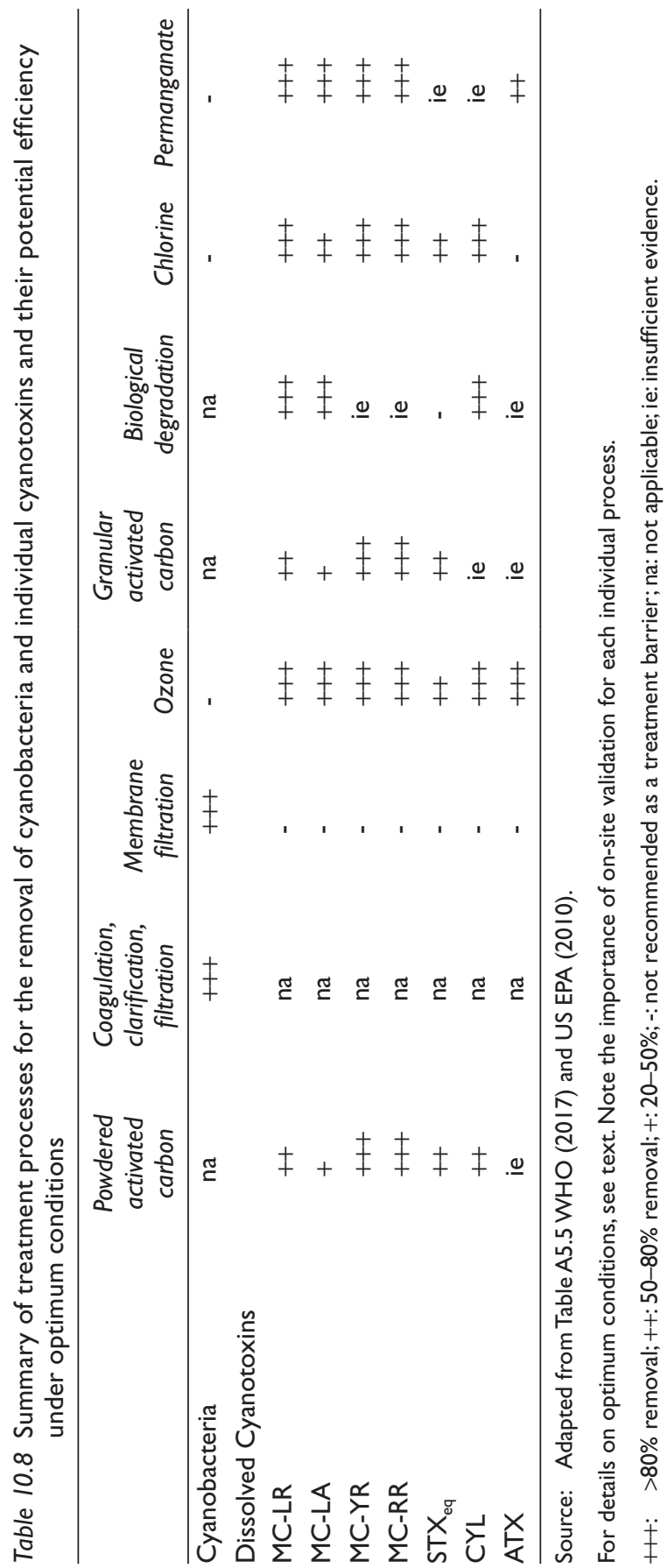


Table 10.8 presents a summary and an assessment of the main treatment measures that can be used for the removal of cyanobacteria and cyanotoxins in a water treatment plant.

\section{I0.4 AFTER THE WATER TREATMENT PLANT - RISKS ASSOCIATED WITH TREATED WATER STORAGE}

After an effective treatment, it is important to ensure drinking-water remains safe and free of cyanobacterial regrowth. This can be accomplished by avoiding open channels and storages where cyanobacteria may proliferate, and by maintaining sufficient chlorine residual throughout the distribution system. Box 10.1 describes an incident of cyanobacterial growth in a small storage reservoir within a regional drinking-water distribution system.

\section{BOX 10.I: CYANOBACTERIAL BLOOM, YORKE PENINSULA DRINKING-WATER SUPPLY (SOUTH AUSTRALIA)}

In April 2000, a cyanobacterial bloom in a treated water storage within the distribution system on the Yorke Peninsula of South Australia led to drinking-water supplied to 15000 people in 15 towns being declared unsafe for 8 days. In addition to permanent residents, the Yorke Peninsula is a popular vacation area for thousands of South Australian residents during holiday periods. The incident occurred over the Easter long weekend.

The incident began on 13-14 April when complaints from residents about musty tastes and odours led to the detection of the benthic cyanobacterium Phormidium aff. formosum in the Upper Paskeville Reservoir. The reservoir was an unroofed shallow $185 \mathrm{~mL}$ storage of filtered chloraminated drinking-water. The odours were caused by the nontoxic cyanobacterial metabolite 2-methyl isoborneol (MIB). The reservoir was taken out of service on 14 April and, although Phormidium was regarded as being nontoxic, precautionary testing of cell extracts using a mouse bioassay was initiated due to the unique nature of the detection. Positive bioassay results were reported on Tuesday 18 April. The State Health Department and the water utility (SA Water) immediately advised the public not to use the water for drinking and cooking. Free bottled water was supplied for all residents and visitors, and bulk water supplies were carted to major consumers of water, including local food manufacturers.

A mains flushing programme was commenced and further testing of cell extracts was initiated. The testing showed that the toxin was inactivated by boiling and chlorination, but not by chloramination. As a result, mains flushing with chloraminated water was replaced with chlorinated water, and the public was advised that the water could be used for drinking and cooking after 
being boiled. The public was given daily updates on the progress of flushing through joint media conferences convened by the health department and the water utility. Sections of the distribution system were gradually cleared from 2l April, and the whole system was declared safe on 25 April.

There was no evidence of any human health impacts caused by the incident, and a survey of the affected community and local businesses showed that actions undertaken by the health department and the water utility were supported and effective. Visitor numbers over the Easter long weekend were not reduced compared to previous years. Provision of alternative sources of drinking-water and the issuing of daily updates were seen as key factors in minimising concerns and impacts of the incident.

Subsequent investigations showed that the toxin was strongly associated with cellular material, was barely soluble and was not one of the established cyanotoxins (microcystin, cylindrospermopsin, anatoxin) or lipopolysaccharide (Baker et al., 200I). Oral dosing of mice did not produce evidence of toxicity. A roof was installed on the reservoir, and there has been no recurrence of the incident.

\subsection{ASSESSING AND REDUCING THE RISK OF CYANOTOXIN BREAKTHROUGH IN DRINKING-WATER TREATMENT IN THE CONTEXT OF A WATER SAFETY PLAN}

While optimising processes in the water treatment plant is an important measure for minimising the risk of cyanotoxins entering the drinking-water system, it is best integrated into the overall Water Safety Plan (WSP) for the supply, as introduced in Chapter 6. This includes an assessment of risks from cyanotoxins together with those from other hazards potentially challenging a water supply as well as identifying the critical points/processes within the supply chain that prevent occurrence, remove hazards through treatment and prevent regrowth in the distribution network. For cyanobacteria, this includes preventing toxin release from cells. A further essential part of the WSP concept is routine operational monitoring of the critical control measures and processes identified during the risk assessment to ensure their optimum operation, both in the presence and in the absence of a cyanobacteria challenge. Table 10.9 presents examples of some control measures that may be implemented in drinking-water treatment and some options for routine monitoring of their reliable operation.

A further important element of a WSP is validation of the efficacy of the control measures. Box 10.2 shows an example of how this was done for a specific water treatment plant. For cyanobacteria and their toxins, this is best achieved through investigative sampling when a bloom challenges the treatment. The most effective way to verify that the system of control measures is effective for cyanobacteria and cyanotoxin removal is systematic 
Table 10.9 Examples of control measures for drinking-water treatment with options for monitoring their functioning

\section{Examples of control measures for drinking-water} treatment

Options for monitoring their functioning

Terminate pre-oxidation measures during cyanobacteria bloom

On-line measurement of cyanobacterial cell density at intake

(e.g., fluorometry)

Inspection of operating records to monitor timely termination of pre-oxidation

Regular visual inspection of waterbody at the raw water intake

Ensure a sufficient supply of the most effective PAC available for immediate use if required

Check PAC batches delivered for compliance to specification

Check sufficient PAC available on site at the beginning of the cyanobacteria high-risk period

Determine approximate PAC dose based on toxin concentrations or maximum expected toxin concentrations estimated from $3 \mu \mathrm{g}$ toxin per $\mathrm{mm}^{3}$ biovolume or I $\mu \mathrm{g}$ toxin per $\mu \mathrm{g}$ chlorophyll- $a$ (see Chapter 5)

Optimise coagulation for the removal of colour and turbidity

Maintain GAC contact time at $\geq 10 \mathrm{~min}$ Replace GAC when required to ensure cyanotoxin removal

Monitor intake cell numbers

Record plant flow; inspect records of PAC dosing

Record turbidity on-line and define corrective action if threshold level is exceeded

Monitor GAC filter loading rates and verify that they result in a sufficient contact time for cyanotoxin removal Periodically test GAC for toxin removal a

Maintain ozone dose to produce a residual Record ozone concentration online at the outlet of this treatment step of $\geq 0.3 \mathrm{mg} / \mathrm{L}$ for a contact time $\geq 5 \mathrm{~min}$ Record chlorine concentration on-line at the outlet of this treatment step of $\geq 100 \mathrm{mg} \mathrm{min} / \mathrm{L}$

Laboratory column testing of GAC can be used as an indication of the removals to be expected in the full scale. If this includes comparison with a sterilised sample, additional removal due to biological activity can be identified.

investigative sampling through the treatment plant during a bloom. The list below presents some examples of important measures to ensure the results are representative of the actual treatment process efficiencies. Note that this list is not comprehensive and needs to be adapted to the specific steps of the given treatment train:

- Develop a sampling procedure that identifies sampling points and describes sampling and sample handling practices.

- Have sampling packs (sampling procedure, sample bottles, filters, a template to record sample names and numbers, dates and times) ready 
and several staff members trained so the response to a challenge can be immediate.

- Measure both total and dissolved toxins at the inlet to the plant to investigate the removal efficiency for each fraction.

- To quantify the efficacy of each step in the treatment train, realise that concentrations in the raw water can vary rapidly; therefore, prepare a list or table of the time each slug of water resides in a unit of the treatment process, and take each subsequent sample to quantify removals (or release) after the appropriate time lapse, equivalent to the detention time in the respective unit of the process, to ensure the results represent, as close as possible, the same slug of water.

- When powdered activated carbon (PAC) is used, take sample to determine the effectiveness for the removal of dissolved metabolites. As PAC is effective only while in suspension, samples should be taken prior to the sedimentation step.

- Samples taken after PAC dosing should be immediately filtered as the PAC may continue to adsorb metabolites over time and will thus give an inaccurate indication of plant performance.

\section{BOX 10.2: CASE STUDY: A SYSTEM RISK ASSESSMENT FOR CYANOTOXIN CONTROL}

When a water utility began to experience customer complaints due to earthy/musty tastes and odours caused by a cyanobacterial bloom in the raw water supply, water quality managers and plant operators realised there was also a potential risk of breakthrough of cyanotoxins into the drinking-water. While waiting for results of toxin analysis, they undertook an assessment of the barriers in place in the treatment plant for the removal of cyanobacterial cells and their metabolites as well as actions to minimise the risks of cyanotoxin breakthrough. The process took place in three steps:

- Identify: Identification of all of the points of potential control and risk;

- Assess: Assessment of the critical points of control and risk;

- Optimise: Optimisation of the control measures and minimisation of the risks.

After these steps had been completed, a verification process was undertaken to ensure the control measures were functioning as expected. 


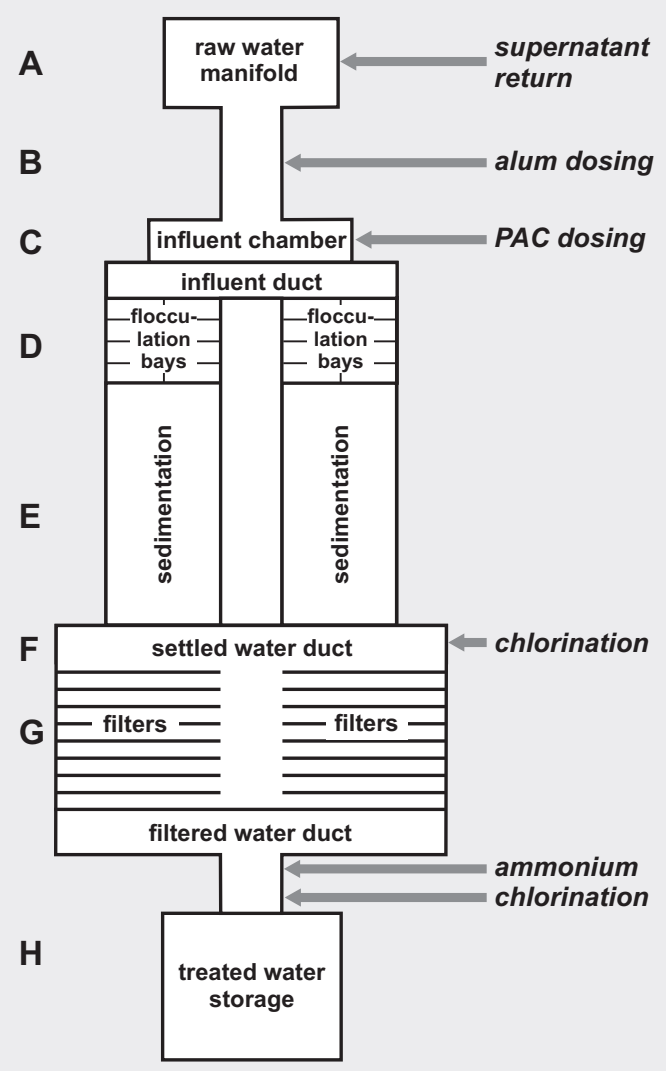

\section{STEPI: IDENTIFICATION OF POINTS OF POTENTIAL CONTROL AND RISK}

A schematic of the plant (see figure) was drafted to aid in the identification of points within the plant that might be either helping to control, or contributing to, the problem of toxin (or more general, metabolite) breakthrough into the distribution system.

The following points of potential control and risk were identified:

A - Cell breakup in pumps could cause the release of dissolved metabolites. Return of sludge supernatant could be contributing to the metabolite load within the plant.

B - Cell breakup in mixing chambers/flocculation bays could cause the release of dissolved metabolites. 
C - PAC, the only barrier to dissolved metabolites, was added shortly after the coagulant, alum, resulting in an immediate capture in the floc. The effectiveness of the PAC had not been verified and was unknown at this stage.

D - Coagulation of cells should result in a significant removal of the metabolites bound within intact cells. However, coagulation resulted in a rapid $\mathrm{pH}$ change (7.5-8 to 6.5 ), and the question as to whether this rapid change in $\mathrm{pH}$ could damage cells was identified as an uncertainty to resolve.

E - The sedimentation tanks were large, with a sludge detention time of up to several days. A risk of toxin release was identified if the cyanobacteria captured in the sludge lysed. There was also a risk of an accumulation of any un-coagulated cyanobacteria in these basins.

F - Cell carry-over to the chlorination point prior to filters: if a removal of approximately $95 \%$ of cyanobacteria is expected, this could result in considerable cell carry-over (in absolute numbers) to the post-sedimentation chlorination point, with the subsequent release of metabolites prior to filtration.

$\mathrm{G}$ - Metabolite release may occur if some cells or flocs are retained in the filters.

$\mathrm{H}$ - Monochloramine was not a barrier for cyanotoxins. The current disinfection regime did not achieve an adequate free chlorine CT.

\section{STEP 2: ASSESSMENT OF THE CRITICAL POINTS OF CONTROL AND RISK}

Controls: This plant had three potential barriers to cyanotoxins:

- PAC application;

- coagulation;

- chlorination.

Risks: Using operator knowledge and previous monitoring, the three major risks were identified as follows:

- recycled sludge supernatant entering the plant inlet;

- cell lysis in the sedimentation tanks;

- accumulation of toxic cyanobacteria on the surface of the sedimentation tanks. 


\section{STEP 3: OPTIMISATION OF THE CONTROL MEASURES AND MINIMISATION OF THE RISKS}

Controls:

- Coagulation at the plant was well managed, and the regular on-line monitoring of turbidity to optimise the coagulation process was considered to be sufficient for the optimisation of cell removal. $\mathrm{pH}$ was monitored closely to ensure it remained above 6.5.

- PAC was an expensive control method, and little was known regarding its effectiveness within the plant. As an interim measure, the dose was increased to the highest practicable within the plant until toxin analysis results were received.

- The disinfection process was modified temporarily to ensure a chlorine $\mathrm{CT}$. The chlorine dose prior to the filters was increased, and the final chlorine dose was reduced. Although the CT remained below 20 $\mathrm{mg} \times \mathrm{min} / \mathrm{L}$ due to engineering constraints, it was considered a more effective barrier than the previous process of chloramination.

Risks:

- Supernatant recycling was terminated until the risk could be quantified by toxin analysis.

- Sludge removal from the sedimentation basin was increased in frequency to ensure a sludge detention time of $<$ I day.

- Visual monitoring of the surface of the sedimentation tanks was undertaken by the operator twice daily to allow the rapid identification of any accumulation of cyanobacteria on the surface. A portable pump that could be used to remove any cyanobacterial accumulation to waste was on stand-by if required.

Longer-term investigations and operational changes were undertaken to reduce future cyanotoxin risk using the findings of the system risk assessment.

\section{LABORATORY STUDIES}

Powdered activated carbon (PAC) testing was undertaken to determine

- the most effective PAC available on the market;

- expected metabolite removals under plant conditions;

- optimum dosing location and concentration of PAC. 
Chlorination testing was undertaken to determine

- necessary CT values for the elimination of a range of toxins that could potentially challenge the water treatment plant;

- the appropriate configuration of the disinfection process to ensure a sufficient $\mathrm{CT}$ as well as an effective monochloramine production.

\section{INFRASTRUCTURE MODIFICATION}

- A PAC precoagulation contact tank was installed to ensure the optimum value from the adsorbent.

- A change in the disinfection regime was implemented to ensure a chlorine $\mathrm{CT}$ of at least $100 \mathrm{mg} \times \mathrm{min} / \mathrm{L}$ prior to ammonium addition.

\section{PROCESS AND SYSTEM MODIFICATION}

- A cyanotoxin response plan was developed by operators and water quality managers, and implemented at the plant.

Investigative sampling was undertaken on a regular basis to verify control measures were optimised.

\section{IN-PLANT VERIFICATION OF THE EFFICIENCY OF THE CONTROL MEASURES}

After the measures described above were put in place, the operators undertook a systematic investigative sampling through the plant to verify that each treatment step and control point was functioning to minimise the risk of cyanotoxin breakthrough into the distribution system. Duplicate samples were taken at each of the points $\mathrm{A}-\mathrm{H}$ identified (see figure) for both total and dissolved metabolites to determine the removal of cells and cyanotoxins.

The results provided some useful insights into the efficiency of the control measures in place at the plant:

- Toxic Microcystis was present in the raw water. Microcystin-LR concentration was 3-5 $\mu \mathrm{g} / \mathrm{L}$, of which $75 \%$ was intracellular.

- PAC reduced the dissolved toxin by approximately $20 \%$.

- Coagulation reduced the intracellular toxins to below detection.

- No increase in dissolved toxin was detected in the sedimentation basin.

- The available free chlorine CT reduced the dissolved toxin to the below detection limit.

No toxin was detected in the sludge treatment supernatant so recycling was reintroduced. 
Note that taste and odour episodes caused by methylisoborneol (MIB) and/or geosmin do not necessarily indicate the presence of cyanotoxins; however, they may be more common than toxic blooms in the raw water source (see also section 2.9). Levels of MIB or geosmin can be measured through the plant using the procedure described above. These compounds will respond differently to the activated carbon and oxidation steps. However, for assessing the efficacy of some treatment steps, they can be used as a surrogate, for example, as an indicator of removals through coagulation, damage to cyanobacteria and release of metabolites.

A Water Safety Plan (WSP) supports day-to-day operations under normal circumstances, which may include "normal" amounts of cyanobacteria in the raw water. Heavy blooms may require additional control, and it is important to develop an emergency response plan that is integrated within the WSP framework for timely and effective responses, as discussed in Chapter 15. It is important that the staff of a treatment plant is familiar with both the WSP and the integrated emergency response plan. Audits are useful for this purpose and should include interviews with staff to check their familiarity with these plans and, for example, whether training exercises of responses to bloom events are periodically conducted.

\section{I0.6 ACHIEVEMENT OF CYANOTOXIN GUIDELINE VALUES}

Clearly, the ultimate objective of the application of treatment measures for the control of cyanobacteria and cyanotoxins is the provision of safe drinking-water. For the cyanotoxins, this means achieving the provisional WHO guideline values of $1 \mu \mathrm{g} / \mathrm{L}$ for MC-LR and $0.7 \mu \mathrm{g} / \mathrm{L}$ for CYN - or for transient short episodes, at least the short-term guideline values for these toxins or the health-based reference value for ATX and the acute value for STX given in Table 5.1 (Note that while the provisional guideline values for MCs are given for MC-LR, the recommendation is to apply them to the sum of all MCs). As emphasised throughout this chapter, the removal achieved, and therefore the ability to achieve the guideline values, is strongly affected by site-specific conditions and therefore requires laboratory testing, monitoring of treatment processes and validation of treatment steps.

Once the effectiveness of treatment process is determined, it is possible to calculate the maximum tolerable concentrations (MTCs) of cyanobacteria and cyanotoxins in the raw water that can be controlled by the existing treatment measures to ensure the production of safe drinking-water. The calculation proposed by Schmidt et al. (2002) is:

$$
\mathrm{MTC}=\frac{\mathrm{GV}}{1-\eta}
$$


where GV is the guideline value and $\eta$ is the achievable fraction removal for dissolved or cell-bound cyanotoxins.

For example, for $\mathrm{CYN}$ with $\mathrm{GV}=0.7 \mu \mathrm{g} / \mathrm{L}$, for a plant with powdered activated carbon (PAC) achieving 70\% CYN removal, the MTC of dissolved CYN in the raw water would be $0.7 / 0.3=2.3 \mu \mathrm{g} / \mathrm{L}$ (in face of the barriers in place in this given plant).

The application of the concept of MTC to cell-bound toxins requires a measure for the toxin content per cell, or cell quota. This can be determined locally by cell counts via microscopy (see section 13.3) and analysing cellbound microcystin concentrations (see Chapter 14). In Chapter 2, Table 2.3 presents some literature values for $\mathrm{MC}$ content per cell ranging from 5 to $553 \mathrm{fg} / \mathrm{cell}$ with an average of $115 \mathrm{fg} / \mathrm{cell}\left(=115 \times 10^{-9} \mu \mathrm{g} / \mathrm{cell}\right)$. This range of variation is wide, and furthermore, published cell quota are largely limited to Microcystis. Operators of a treatment plant therefore best periodically determine the cell quota of the cyanobacteria currently present during a bloom. Using a cell quota of $115 \mathrm{fg} / \mathrm{cell}$ for intracellular MC, the guideline value is reached by a cell concentration (cell equivalent) of:

$$
\text { Cell equivalent }=\frac{1 \frac{\mu \mathrm{g}}{\mathrm{L}}}{115 \times 10^{-9} \frac{\mu \mathrm{g}}{\mathrm{cell}}}=8695652 \frac{\mathrm{cells}}{\mathrm{L}}=8696 \frac{\mathrm{cells}}{\mathrm{mL}}
$$

If we estimate the cell removal by coagulation, $\eta$, at $90 \%$, a conservative estimate of the MTC in cells/mL is given by

$$
\text { MTC }=\frac{8696 \frac{\text { cells }}{\mathrm{mL}}}{0.10}=86957 \frac{\text { cells }}{\mathrm{mL}}
$$

A similar calculation for the minimum and maximum values for cell quotas given above amounts to MTCs of $20000 / 0.1=200000$ cells $/ \mathrm{mL}$ and 1808/0.1 =18 080 cells $/ \mathrm{mL}$, respectively. Therefore, these calculations indicate that a treatment plant achieving $90 \%$ removal of cell-bound toxin through coagulation can achieve the guideline value of MC-LR through this one treatment step when challenged by concentrations between 18080 cells $/ \mathrm{mL}$ (minimum MTC) and 200000 cells $/ \mathrm{mL}$ (maximum MTC), provided the cell quota for microcystins is in the range given above.

In practice, both dissolved and cell-bound toxins will be present in raw water, and most treatment plants will have multiple barriers in place. A simple spreadsheet calculator as described by Zamyadi et al. (2018) supports these calculations. Cumulative removals of both dissolved and cellbound toxins can then be taken into account when calculating the MTCs for individual treatment plants. 
As these estimates indicate, guideline values should be achievable in an optimised treatment plant with multiple barriers in place where toxin removals are cumulative, under moderate conditions of cyanobacterial challenge. Calculations are best undertaken on a site-by-site basis as an important element of a cyanotoxin management plan (best developed as part of a Water Safety Plan [WSP]; see above). Furthermore, while estimates like those given by these calculations serve as point of departure, where mitigating cyanobacterial occurrence in the raw water is not successful or insufficient, the most effective way to ensure that guideline values are achieved is through periodic validation of the treatment process (most effectively when challenged by blooms) combined with monitoring of cyanotoxin concentrations in treated water during periods of cyanobacterial occurrence in the raw water.

\section{REFERENCES}

Acero JL, Rodriguez E, Meriluoto J (2005). Kinetics of reactions between chlorine and the cyanobacterial toxins microcystins. Water Res. 39:1628-1638.

Al Momani F, Smith DW, El-Din MG (2008). Degradation of cyanobacteria toxin by advanced oxidation processes. J Hazard Mat. 150:238-249.

Antoniou MG, de la Cruz AA, Dionysiou DD (2010). Intermediates and reaction pathways from the degradation of microcystin-LR with sulfate radicals. Environ Sci Technol. 44:7238-7244.

Aparecida Pera do Amaral P, Coral LA, Nagel-Hassemer ME, Belli TJ, Lapolli FR (2013) Association of dissolved air flotation (DAF) with microfiltration for cyanobacterial removal in water supply. Desal Water Treat. 51:1664-1671.

AWWA (2019). Resources \& Tools. Available at: https://www.awwa.org/ Resources-Tools/water-knowledge/cyanotoxins.

Baker PD, Steffensen DA, Humpage AR, Nicholson BC, Falconer IR, Lanthois B et al. (2001). Preliminary evidence of toxicity asociated with the benthic cyanobacetrium Phormidium in South Australia. Environ Toxicol. 16:506-511.

Brooke S, Newcombe G, Nicholson B, Klass G (2006). Decrease in toxicity of microcystins LA and LR in drinking water by ozonation. Toxicon. 48:1054-1059.

Bruchet A, Bernazeau F, Baudin I, Pieronne P (1998). Algal toxins in surface waters: analysis and treatment. Water Supply. 16:619-623.

Capelo-Neto J, Buarque NMS (2016). Simulation of saxitoxins adsorption in fullscale GAC filter using HSDM. Water Res. 88:558-565.

Carlile P (1994). Further studies to investigate microcystin-LR and anatoxin-a removal from water. Report FR 0458. Denver (CO): Water Research Foundation.

Chen H, Lu X, Deng C, Yan X (2009). Facile synthesis of uniform microspheres composed of a magnetite core and copper silicate nanotube shell for removal of microcystins in water. J Phys Chem C. 113:21068-21073.

Chen Y, Zhang X, Liu Q, Wang X, Xu L, Zhang Z (2015). Facile and economical synthesis of porous activated semi-cokes for highly efficient and fast removal of microcystin-LR. J Hazard Mat. 299:325-332. 
Cheng XL, Shi HL, Adams CD, Timmons T, Ma YF (2009). Effects of oxidative and physical treatments on inactivation of Cylindrospermopsis raciborskii and removal of cylindrospermopsin. Wat Sci Technol. 60:689-697.

Chow C, Panglisch S, House J, Drikas M, Burch M, Gimbel R (1997). Study of membrane filtration for the removal of cyanobacterial cells. AQUA. 46:324-334.

Christoffersen K, Lyck S, Winding A (2002). Microbial activity and bacterial community structure during degradation of microcystins. Aquat Microb Ecol. 27:125-136.

Cook D, Newcombe G (2008). Comparison and modeling of the adsorption of two microcystin analogues onto powdered activated carbon. Environ Technol. 29:525-534.

Coral LA, Zamyadi A, Barbeau B, Bassetti FJ, Lapolli FR, Prevost M (2013). Oxidation of Microcystis aeruginosa and Anabaena flos-aquae by ozone: impacts on cell integrity and chlorination by-product formation. Water Res. 47:2983-2994.

Cornish BJPA, Lawton LA, Robertson PKJ (2000). Hydrogen peroxide enhanced photocatalytic oxidation of microcystin-LR using titanium dioxide. Appl Photocatal B: Environ. 25:59-67.

Craig K, Bailey D (1995). Cyanobacterial toxin microcystin-LR removal using activated carbon-Hunter Water Corporation Experience. Proceedings of the 16th AWWA Federal Convention. Sydney, Australia: AWWA:579-586.

Dai G, Quan C, Zhang X, Liu J, Song L, Gan N (2012). Fast removal of cyanobacterial toxin microcystin-LR by a low-cytotoxic microgel-Fe (III) complex. Water Res. 46:1482-1489.

De Julio M, Fioravante D, De Julio T, Oroski F, Graham N (2010). A methodology for optimising the removal of cyanobacteria cells from a brazilian eutrophic water. Braz J Chem Eng. 27:113-126.

Deng Y, Qi D, Deng C, Zhang X, Zhao D (2008). Superparamagnetic high-magnetization microspheres with an $\mathrm{Fe}_{3} \mathrm{O}_{4} @ \mathrm{SiO}_{2}$ core and perpendicularly aligned mesoporous $\mathrm{SiO}_{2}$ shell for removal of microcystins. J Am Chem Soc. 130:28-29.

Ding J, Shi H, Timmons T, Adams C (2010). Release and removal of microcystins from Microcystis during oxidative-, physical-, and UV-based disinfection. J Environ Eng. 136:2-11.

Dixon M, Ho L, Chow C, Newcombe G, Croue JP, Cigana J et al. (2012). Evaluation of integrated membranes for T\&O and toxin control. Denver (CO): Water Research Foundation.

Donati C, Drikas M, Hayes R, Newcombe G (1994). Microcystin-LR adsorption by powdered activated carbon. Water Res. 28:1735-1742.

Dreyfus J, Monrolin Y, Pestana CJ, Reeve PJ, Sawade E, Newton K et al. (2016). Identification and assessment of water quality risks associated with sludge supernatant recycling in the presence of cyanobacteria. J Water Supply: Res Technol-AQUA. 65:441-452.

Drikas M, Chow CW, House J, Burch MD (2001). Using coagulation, flocculation and settling to remove toxic cyanobacteria. J - Am Water Works Assoc. 93:100-111.

Drogui P, Daghrir R, Simard M-C, Sauvageau C, Blais JF (2012). Removal of microcystin-LR from spiked water using either activated carbon or anthracite as filter material. Environ Technol. 33:381-391. 
Dugan NR, Smith SJ, Sanan TT (2018). Impacts of potassium permanganate and powdered activated carbon on cyanotoxin release. J Am Water Works Assoc. 110:E31-E42.

Dugan NR, Williams DJ (2006). Cyanobacteria passage through drinking water filters during perturbation episodes as a function of cell morphology, coagulant and initial filter loading rate. Harmful Algae. 5:26-35.

El-Sheikh SM, Khedr TM, Zhang G, Vogiazi V, Ismail AA, O'Shea K et al. (2017). Tailored synthesis of anatase-brookite heterojunction photocatalysts for degradation of cylindrospermopsin under UV-Vis light. Chem Eng J. 310:428-436.

Fan J, Ho L, Hobson P, Daly R, Brookes J (2014). Application of various oxidants for cyanobacteria control and cyanotoxin removal in wastewater treatment. J Environ Eng. 140:04014022.

Fan J, Rao L, Chiu Y-T, Lin T-F (2016). Impact of chlorine on the cell integrity and toxin release and degradation of colonial Microcystis. Water Res. 102:394-404.

Feitz AJ, Waite TD, Jones GJ, Boyden BH, Orr PT (1999). Photocatalytic degradation of the blue green algal toxin microcystin-LR in a natural organic-aqueous matrix. Environ Sci Technol. 33:243-249.

Fotiou T, Triantis TM, Kaloudis T, O'Shea KE, Dionysiou DD, Hiskia A (2016). Assessment of the roles of reactive oxygen species in the UV and visible light photocatalytic degradation of cyanotoxins and water taste and odor compounds using $\mathrm{C}-\mathrm{TiO}_{2}$. Water Res. 90:52-61.

Garcia ACdA, Rodrigues MAS, Xavier JLN, Gazulla V, Meneguzzi A, Bernardes AM (2015). Degradation of cyanotoxins (microcystin) in drinking water using photoelectrooxidation. Braz J Biol. 75:45-49.

Gijsbertsen-Abrahamse A, Schmidt W, Chorus I, Heijman S (2006). Removal of cyanotoxins by ultrafiltration and nanofiltration. J Memb Sci. 276:252-259.

Goslan EH, Seigle C, Purcell D, Henderson R, Parsons SA, Jefferson B et al. (2017). Carbonaceous and nitrogenous disinfection by-product formation from algal organic matter. Chemosphere. 170:1-9.

Grützmacher G, Böttcher G, Chorus I, Bartel H (2002). Removal of microcystins by slow sand filtration. Environ Toxicol. 17:386-394.

Hart J, Fawell J, Croll B (1998). The fate of both intra- and extracellular toxins during drinking water treatment. Water Supply. 16:611-616.

He X, Armah A, Hiskia A, Kaloudis T, O'Shea K, Dionysiou DD (2015). Destruction of microcystins (cyanotoxins) by UV-254 nm-based direct photolysis and advanced oxidation processes (AOPs): influence of variable amino acids on the degradation kinetics and reaction mechanisms. Water Res. 74:227-238.

He X, Stanford BD, Adams C, Rosenfeldt EJ, Wert EC (2017). Varied influence of microcystin structural difference on ELISA cross-reactivity and chlorination efficiency of congener mixtures. Water Res. 126:515-523.

He X, Wert EC (2016). Colonial cell disaggregation and intracellular microcystin release following chlorination of naturally occurring Microcystis. Water Res. 101:10-16.

He X, Zhang G, de la Cruz AA, O'Shea KE, Dionysiou DD (2014). Degradation mechanism of cyanobacterial toxin cylindrospermopsin by hydroxyl radicals in homogeneous $\mathrm{UV} / \mathrm{H}_{2} \mathrm{O}_{2}$ process. Environ Sci Technol. 48:4495-4504. 
Hena S, Rozi R, Tabassum S, Huda A (2016). Simultaneous removal of potent cyanotoxins from water using magnetophoretic nanoparticle of polypyrrole: adsorption kinetic and isotherm study. Environ Sci Pollut Res. 23:14868-14880.

Henderson R, Parsons SA, Jefferson B (2008). The impact of algal properties and pre-oxidation on solid-liquid separation of algae. Water Res. 42:1827-1845.

Ho L, Croué J-P, Newcombe G (2004). The effect of water quality and NOM character on the ozonation of MIB and geosmin. Wat Sci Technol. 49:249-255.

Ho L, Kayal N, Trolio R, Newcombe G (2010). Determining the fate of Microcystis aeruginosa cells and microcystin toxins following chloramination. Wat Sci Technol. 62:442-450.

Ho L, Lambling P, Bustamante H, Duker P, Newcombe G (2011). Application of powdered activated carbon for the adsorption of cylindrospermopsin and microcystin toxins from drinking water supplies. Water Res. 45:2954-2964.

Ho L, Newcombe G (2007). Evaluating the adsorption of microcystin toxins using granular activated carbon (GAC). J Water Supply: Res Technol-AQUA. 56:281-291.

Ho L, Onstad G, von Gunten U, Rinck-Pfeiffer S, Craig K, Newcombe G (2006). Differences in the chlorine reactivity of four microcystin analogues. Water Res. 40:1200-1209.

Ho L, Sawade E, Newcombe G (2012a). Biological treatment options for cyanobacteria metabolite removal-A review. Water Res 46:1536-1548.

Ho L, Slyman N, Kaeding U, Newcombe G (2008). Optimizing PAC and chlorination practices for cylindrospermopsin removal. J - Am Water Works Assoc. 100:88.

Ho L, Tang T, Monis PT, Hoefel D (2012b). Biodegradation of multiple cyanobacterial metabolites in drinking water supplies. Chemosphere. 87:1149-1154.

Ho L, Tanis-Plant P, Kayal N, Slyman N, Newcombe G (2009). Optimising water treatment practices for the removal of Anabaena circinalis and its associated metabolites, geosmin and saxitoxins. J Water Health. 7:544-556.

Huo X, Chang D-W, Tseng J-H, Burch MD, Lin T-F (2015). Exposure of Microcystis aeruginosa to hydrogen peroxide under light: kinetic modeling of cell rupture and simultaneous microcystin degradation. Environ Sci Technol. 49:5502-5510.

Jiang X, Lee S, Mok C, Lee J (2017). Sustainable methods for decontamination of microcystin in water using cold plasma and UV with reusable $\mathrm{TiO}_{2}$ nanoparticle coating. Int J Environ Res Public Health. 14:480.

Karthikeyan S, Dionysiou DD, Lee AF, Suvitha S, Maharaja P, Wilson K et al. (2016). Hydroxyl radical generation by cactus-like copper oxide nanoporous carbon catalysts for microcystin-LR environmental remediation. Catal Sci Technol. 6:530-544.

Kayal N, Newcombe G, Ho L (2008). Investigating the fate of saxitoxins in biologically active water treatment plant filters. Environ Toxicol. 23:751-755.

Kennedy AM, Reinert AM, Knappe DR, Summers RS (2017). Prediction of full-scale GAC adsorption of organic micropollutants. Environ Eng Sci. 34:496-507.

Lee J, Walker HW (2011). Adsorption of microcystin-LR onto iron oxide nanoparticles. Colloids Surf A: Physicochem Eng Asp. 373:94-100.

Li X, Pei H, Hu W, Meng P, Sun F, Ma G et al. (2015). The fate of Microcystis aeruginosa cells during the ferric chloride coagulation and flocs storage processes. Environ Technol. 36:920-928. 
Lian L, Cao X, Wu Y, Sun D, Lou D (2014). A green synthesis of magnetic bentonite material and its application for removal of microcystin-LR in water. Appl Surf Sci. 289:245-251.

Liao X, Liu J, Yang M, Ma H, Yuan B, Huang C-H (2015). Evaluation of disinfection by-product formation potential (DBPFP) during chlorination of two algae species-blue-green Microcystis aeruginosa and diatom Cyclotella meneghiniana. Sci Tot Environ. 532:540-547.

Liu J, Cai Y, Deng Y, Sun Z, Gu D, Tu B et al. (2010). Magnetic 3-D ordered macroporous silica templated from binary colloidal crystals and its application for effective removal of microcystin. Micropor Mesopor Mat. 130:26-31.

Liu I, Lawton LA, Cornish BJPA, Robertson PKJ (2002). Mechanistic and toxicity tudies of the photocatalytic oxidation of microcystin-LR. J Photochem Photobiol. 148:349-354.

Liu I, Lawton LA, Robertson PK (2003). Mechanistic studies of the photocatalytic oxidation of microcystin-LR: an investigation of byproducts of the decomposition process. Environ Sci Technol. 37:3214-3219.

Lobón GS, Yepez A, Garcia LF, Morais RL, Vaz BG, Carvalho VV et al. (2017). Efficient electrochemical remediation of microcystin-LR in tap water using designer $\mathrm{TiO}_{2} @$ carbon electrodes. Sci Rep. 7:41326.

Ma J, Lei G, Fang J (2007). Effect of algae species population structure on their removal by coagulation and filtration processes-a case study. J Water Supply: Res Technol-AQUA. 56:41-54.

Ma M, Liu R, Liu H, Qu J (2012). Chlorination of Microcystis aeruginosa suspension: cell lysis, toxin release and degradation. J Hazard Mat. 217:279-285.

Merel S, Clement M, Mourot A, Fessard V, Thomas O (2010). Characterization of cylindrospermopsin chlorination. Sci Tot Environ. 408:3433-3442.

Mohamed ZA (2016). Breakthrough of Oscillatoria limnetica and microcystin toxins into drinking water treatment plants-examples from the Nile River, Egypt. Water SA. 42:161-165.

Mohamed ZA, Deyab MA, Abou-Dobara MI, El-Sayed AK, El-Raghi WM (2015). Occurrence of cyanobacteria and microcystin toxins in raw and treated waters of the Nile River, Egypt: implication for water treatment and human health. Environ Sci Pollut Res. 22:11716-11727.

Mouchet P, Bonnelye V (1998). Solving algae problems: French expertise and worldwide applications. J Water Supply: Res Technol-AQUA. 47:125-141.

Newcombe G, Cook D, Brooke S, Ho L, Slyman N (2003). Treatment options for microcystin toxins: similarities and differences between variants. Environ Technol. 24:299-308.

Newcombe G, Dreyfus J, Monrolin Y, Pestana C, Reeve P, Sawade E et al. (2015). Optimizing conventional treatment for the removal of cyanobacteria and toxins. Denver (CO): Water Research Foundation.

Newcombe G, House J, Ho L, Baker P, Burch M (2010). Management strategies for cyanobacteria (blue-green algae): A guide for water utilities. Adelaide: Water Quality Research Australia (WQRA).

Newcombe G, Nicholson B (2004). Water treatment options for dissolved cyanotoxins. J Water Supply Res. 53:227-239.

Nicholson BC, Rosinato J, Burch MD (1994). Destruction of cyanobacterial peptide hepatotoxins by chlorine and chloramine. Water Res. 28:1297-1303. 
Onstad GD, Strauch S, Meriluoto J, Codd GA, von Gunten U (2007). Selective oxidation of key functional groups in cyanotoxins during drinking water ozonation. Environ Sci Technol. 41:4397-4404.

Pavagadhi S, Tang ALL, Sathishkumar M, Loh KP, Balasubramanian R (2013). Removal of microcystin-LR and microcystin-RR by graphene oxide: adsorption and kinetic experiments. Water Res. 47:4621-4629.

Pestana CJ, Edwards C, Prabhu R, Robertson PK, Lawton LA (2015). Photocatalytic degradation of eleven microcystin variants and nodularin by $\mathrm{TiO}_{2}$ coated glass microspheres. J Hazard Mat. 300:347-353.

Pestana CJ, Reeve PJ, Sawade E, Voldoire CF, Newton K, Praptiwi R et al. (2016). Fate of cyanobacteria in drinking water treatment plant lagoon supernatant and sludge. Sci Tot Environ. 565:1192-1200.

Petrusevski B, van Breemen AN, Alaerts G (1996). Effect of permanganate pretreatment and coagulation with dual coagulants on algae removal in direct filtration. J Water Supply: Res Technol-AQUA. 45:316-326.

Pietsch J, Bornmann K, Schmidt W (2002). Relevance of intra-and extracellular cyanotoxins for drinking water treatment. CLEAN-Soil Air Water. 30:7-15.

Pinho LX, Azevedo J, Brito Â, Santos A, Tamagnini P, Vilar VJ et al. (2015). Effect of $\mathrm{TiO}_{2}$ photocatalysis on the destruction of Microcystis aeruginosa cells and degradation of cyanotoxins microcystin-LR and cylindrospermopsin. Chem Eng J. 268:144-152.

Pyo D, Moon D (2005). Adsorption of microcystin LR by activated carbon fibers. B Korean Chem Soc. 26:2089.

Qian F, Dixon DR, Newcombe G, Ho L, Dreyfus J, Scales PJ (2014). The effect of $\mathrm{pH}$ on the release of metabolites by cyanobacteria in conventional water treatment processes. Harmful Algae. 39:253-258.

Rapala J, Lahti K, Sivonen K, Niemelä SI (1994). Biodegradability and adsorption on lake sediments of cyanobacterial hepatotoxins and anatoxin-a. Lett Appl Microbiol. 19:423-428.

Rodriguez E, Acero JL, Spoof L, Meriluoto J (2008). Oxidation of MC-LR and -RR with chlorine and potassium permanganate: toxicity of the reaction products. Water Res. 42:1744-1752

Rodriguez E, Majado ME, Meriluoto J, Acero JL (2007a). Oxidation of microcystins by permanganate: reaction kinetics and implications for water treatment. Water Res. 41:102-110.

Rodríguez E, Onstad GD, Kull TP, Metcalf JS, Acero JL, von Gunten U (2007). Oxidative elimination of cyanotoxins: comparison of ozone, chlorine, chlorine dioxide and permanganate. Water Res. 41:3381-3393.

Rodriguez E, Sordo A, Metcalf JS, Acero JL (2007b). Kinetics of the oxidation of cylindrospermopsin and anatoxin-a with chlorine, monochloramine and permanganate. Water Res. 41:2048-2056.

Rositano J, Newcombe G, Nicholson B, Sztajnbok P (2001). Ozonation of NOM and algal toxins in four treated waters. Water Res. 35:23-32.

Sathishkumar M, Pavagadhi S, Vijayaraghavan K, Balasubramanian R, Ong S (2010). Experimental studies on removal of microcystin-LR by peat. J Hazard Mat. 184:417-424. 
Sawade E, Ho L, Hoefel D, Newcombe G (2012). Development and validation of the biological filtration potential test for the removal of cyanobacterial metabolites. AWA Ozwater Convention and Exhibition. Sydney: Water Research Australia.

Schmidt W, Willmitzer H, Bornmann K, Pietsch J (2002). Production of drinking water from raw water containing cyanobacteria - Pilot plant studies for assessing the risk of microcystin breakthrough. Environ Toxicol. 17:375-385.

Şengül AB, Tüfekçi N, Aktan S (2016). The use of alum as coagulant for removing cyanobacterial cells in drinking water. Desalin Water Treat. 57:25610-25616.

Senogles P, Shaw GR, Smith MJ, Norris RL, Chiswell RK, Mueller J et al. (2000). Degradation of the cyanobacterial toxin cylindrospermopsin, from Cylindrospermopsis raciborskii, by chlorination. Toxicon. 38:1203-1213.

Senogles P-J, Scott J, Shaw G, Stratton H (2001). Photocatalytic degradation of the cyanotoxin cylindrospermopsin, using titanium dioxide and UV irradiation. Water Res. 35:1245-1255.

Shawwa AR, Smith DW (2001). Kinetics of microcystin-LR oxidation by ozone. Ozone: Sci Eng. 23:161-170.

Shephard GS, Stockenstrom S, de Villiers D, Engelbrecht WJ, Wessels GFS (2002). Degradation of microcystin toxins in a falling film photocatalytic reactor with immobilized titanium dioxide catalyst. Water Res. 36:140-146.

Smith MJ, Shaw GR, Eaglesham GK, Ho L, Brookes JD (2008). Elucidating the factors influencing the biodegradation of cylindrospermopsin in drinking water sources. Environ Toxicol. 23:413-421.

Somdee T, Wibuloutai J, Somdee T, Somdee A (2014). Biodegradation of the cyanobacterial hepatotoxin $\left[\mathrm{Dha}^{7}\right]$ microcystin-LR within a biologically active sand filter. Water Supply. 14:672-680.

Song W, Yan S, Cooper WJ, Dionysiou DD, O'Shea KE (2012). Hydroxyl radical oxidation of cylindrospermopsin (cyanobacterial toxin) and its role in the photochemical transformation. Environ Sci Technol. 46:12608-12615.

Stanford BD, Adams C, Rosenfeldt EJ, Arevalo E, Reinert A (2016). CyanoTOX: tools for managing cyanotoxins in drinking water treatment with chemical oxidants. J Am Water Works Assoc. 108:41-46.

Sun F, Pei H-Y, Hu W-R, Li X-Q, Ma C-X, Pei R-T (2013). The cell damage of Microcystis aeruginosa in $\mathrm{PACl}$ coagulation and floc storage processes. Sep Purif Technol. 115:123-128.

Teixeira MR, Rosa MJ (2006a). Comparing dissolved air flotation and conventional sedimentation to remove cyanobacterial cells of Microcystis aeruginosa: part I: the key operating conditions. Sep Purif Technol. 52:84-94.

Teixeira MR, Rosa MJ (2006b). Neurotoxic and hepatotoxic cyanotoxins removal by nanofiltration. Water Res. 40:2837-2846.

Teixeira MR, Rosa MJ (2007). Comparing dissolved air flotation and conventional sedimentation to remove cyanobacterial cells of Microcystis aeruginosa: part II. The effect of water background organics. Sep Purif Technol 53:126-134.

UKWIR (1996). Pilot scale GAC tests to evaluate toxin removal. London: United Kingdom Water Industry Research. https://www.ukwir.org/reports/96-DW07-1/66681/Pilot-Scale-GAC-Tests-to-Evaluate-Toxin-Removal. 
US EPA (2010). Long term 2 enhanced surface water treatment rule toolbox. Guidance manual. Washington (DC): Environmental Protection Agency of the United States. https://www.epa.gov/dwreginfo/long-term-2-enhancedsurface-water-treatment-rule-documents.

Vlad S, Anderson WB, Peldszus S, Huck PM (2014). Removal of the cyanotoxin anatoxin-a by drinking water treatment processes: a review. J Water Health. 12:601-617.

Wang H, Ho L, Lewis DM, Brookes JD, Newcombe G (2007). Discriminating and assessing adsorption and biodegradation removal mechanisms during granular activated carbon filtration of microcystin toxins. Water Res. 41:4262-4270.

Wang Z, Wang C, Wang P, Qian J, Hou J, Ao Y (2015). Response surface modeling and optimization of microcystin-LR removal from aqueous phase by polyacrylamide/sodium alginate-montmorillonite superabsorbent nanocomposite. Desalin Water Treat. 56:1121-1139.

Wert EC, Korak JA, Trenholm RA, Rosario-Ortiz FL (2014). Effect of oxidant exposure on the release of intracellular microcystin, MIB, and geosmin from three cyanobacteria species. Water Res. 52:251-259.

WHO (2015). Management of cyanobacteria in drinking-water supplies: information for regulators and water suppliers. Geneva: World Health Organization. https://apps.who.int/iris/handle/10665/153970

WHO (2017). Technical Brief: Water quality and health-review of turbidity: information for regulators and water suppliers. Geneva: World Health Organization. http://https://apps.who.int/iris/handle/10665/254631

Wu C-C, Huang W-J, Ji B-H (2015). Degradation of cyanotoxin cylindrospermopsin by $\mathrm{TiO} 2$-assisted ozonation in water. J Environ Sci Health Part A. 50:1116-1126.

Xagoraraki I, Zulliger K, Harrington GW, Zeier B, Krick W, Karner DA (2006). CT values required for degradation of microcystin-LR by free chlorine. J Water Supply: Res Technol-AQUA. 55:233-245.

Yan S, Jia A, Merel S, Snyder SA, O’Shea KE, Dionysiou DD et al. (2016). Ozonation of cylindrospermopsin (cyanotoxin): degradation mechanisms and cytotoxicity assessments. Environ Sci Technol. 50:1437-1446.

Yap R, Whittaker M, Peirson W, Jefferson B, Stuetz R, Newcombe G et al. (2012). The impact of Microcystis aeruginosa strain on cell removal using bubbles modified with poly(diallyldimethyl ammonium chloride). 6th International Conference on Flotation for Water and Wastewater Systems. New York, USA.

Zamyadi A, Coral LA, Barbeau B, Dorner S, Lapolli FR, Prévost M (2015). Fate of toxic cyanobacterial genera from natural bloom events during ozonation. Water Res. 73:204-215.

Zamyadi A, Dorner S, Ndong M, Ellis D, Bolduc A, Bastien C et al. (2013a). Lowrisk cyanobacterial bloom sources: Cell accumulation within full-scale treatment plants. J Am Water Works Assoc. 105.

Zamyadi A, Dorner S, Sauvé S, Ellis D, Bolduc A, Bastien C et al. (2013b). Speciesdependence of cyanobacteria removal efficiency by different drinking water treatment processes. Water Res 47:2689-2700. 
Zamyadi A, Henderson R, Newton K, Capelo-Neto J, Newcombe G (2018). Assessment of the water treatment process's empirical model predictions for the management of aesthetic and health risks associated with cyanobacteria. Water. 10:590.

Zamyadi A, Ho L, Newcombe G, Bustamante H, Prévost M (2012a). Fate of toxic cyanobacterial cells and disinfection by-products formation after chlorination. Water Res. 46:1524-1535.

Zamyadi A, Ho L, Newcombe G, Daly RI, Burch M, Baker P et al. (2010). Release and oxidation of cell-bound saxitoxins during chlorination of Anabaena circinalis cells. Environ Sci Technol. 44:9055-9061.

Zamyadi A, MacLeod SL, Fan Y, McQuaid N, Dorner S, Sauvé S et al. (2012b). Toxic cyanobacterial breakthrough and accumulation in a drinking water plant: a monitoring and treatment challenge. Water Res. 46:1511-1523.

Zhang G, Zhang YC, Nadagouda M, Han C, O‘Shea K, El-Sheikh SM et al. (2014). Visible light-sensitized S, $\mathrm{N}$ and $\mathrm{C}$ co-doped polymorphic $\mathrm{TiO}_{2}$ for photocatalytic destruction of microcystin-LR. Appl Catal B: Environ. 144:614-621.

Zhang H, Dan Y, Adams CD, Shi H, Ma Y, Eichholz T (2017). Effect of oxidant demand on the release and degradation of microcystin-LR from Microcystis aeruginosa during oxidation. Chemosphere. 181:562-568.

Zhang X, Li J, Yang J-Y, Wood KV, Rothwell AP, Li W et al. (2016). Chlorine/UV process for decomposition and detoxification of microcystin-LR. Environ Sci Technol. 50:7671-7678.

Zhao H, Qiu J, Fan H, Li A (2013). Mechanism and application of solid phase adsorption toxin tracking for monitoring microcystins. J Chromatogr A. 1300:159-164.

Zhou S, Shao Y, Gao N, Li L, Deng J, Zhu M et al. (2014). Effect of chlorine dioxide on cyanobacterial cell integrity, toxin degradation and disinfection by-product formation. Sci Tot Environ. 482:208-213.

Zhu G, Lu X, Yang Z (2015). Characteristics of UV-MicroO ${ }_{3}$ reactor and its application to microcystins degradation during surface water treatment. J Chem. Article ID 240703.

Zong W, Sun F, Pei H, Hu W, Pei R (2015). Microcystin-associated disinfection by-products: The real and non-negligible risk to drinking water subject to chlorination. Chem Eng J. 279:498-506. 